\title{
The Reception of The Ladies Paradise in Nineteenth- Century England and the Fight Against Sensual Capitalism
}

\author{
by Diana Kolesnik
}

A thesis submitted to the Faculty of Graduate and Postdoctoral Affairs in partial fulfilment of the requirements for the degree of

Master of Arts

In

Political Economy

Carleton University

Ottawa, Ontario

(C) 2020

Diana Kolesnik 


\section{Acknowledgments}

From the bottom of my heart I would like to express my deep and sincere gratitude to my research supervisor, Professor Danielle Kinsey for guiding me and motivating me throughout my research. Her optimism, insight and vision helped push me and inspire me when things got tough. Her humor, wit and knowledge kept me engaged and eager to learn more about history and literature. It has been a great privilege and honor to work alongside Professor Kinsey and I am incredibly grateful for everything she has done for me throughout this experience. I truly could not have done this without her support.

I would also like to say thank you to my committee, Professor Sarah Brouillette and Professor Justin Paulson. Though our committee was formed only in the very late stages of my thesis, I am sincerely grateful for them accepting to be part of my thesis committee. Without their time and comments, my thesis submission would not have been possible. Thank you, truly.

I am also extending my gratitude to Carleton University for accepting me into the Political Economy program and allowing me to be part of such a great institution. This has been a fantastic experience and I have learned so much going forward.

Finally, I wish to say a big thank you to my partner Ege and his family, without whom my studies would have been impossible. You have been my light in the darkest of times and I am forever grateful for your support. 


\begin{abstract}
The aim of this thesis is to show how through studying Émile Zola's The Ladies Paradise (1883), we can develop a stronger understanding of late Victorian political economy. It argues that this novel should be considered as a political economic text. Further, I suggest that some late Victorians were very hesitant to embrace unbridled sensual capitalism for fear of enticing increased women's right movements. I discuss this through exploring the reception of the novel and writings produced by late Victorian conservative thinker and antifeminist Lynn Linton.
\end{abstract}

While debates about political economy were taken up by Karl Marx and Walter Bagehot in the realm of economic and "high" political discourse, the texture of their engagement was not focused on the lived experiences of consumerism for women of the middling and even working classes. This led to a limited scope in terms of understanding Victorian political economy that left out or deactivated consumers. Considering the rich world of literature and the reactions against it offers a fuller picture of how consumer practice and culture invigorated political economy. A theoretical approach on sensual capitalism as outlined by Bryan Nelson and David Howes, combined with twentieth-century consumption theorists, will inform my arguments throughout in order to contextualize what I argue is an underemphasis on the experiences and motivations of female consumers in Bagehot and Marx's theories. 


\section{Table of Contents}

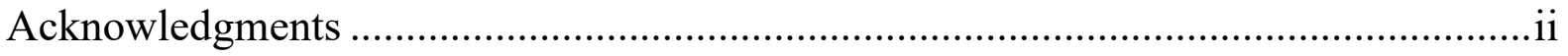

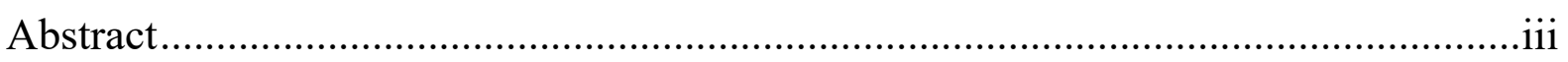

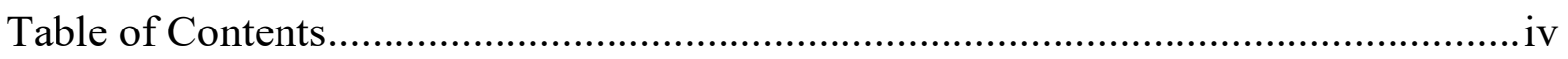

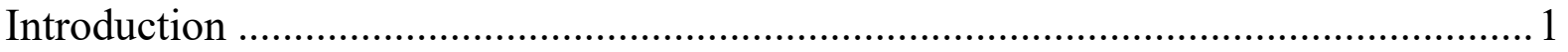

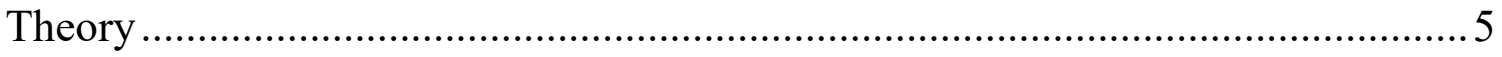

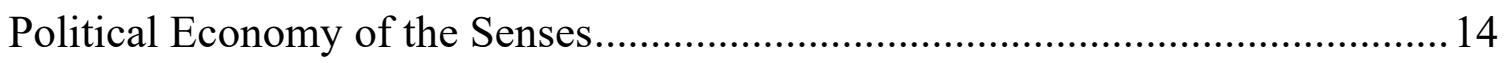

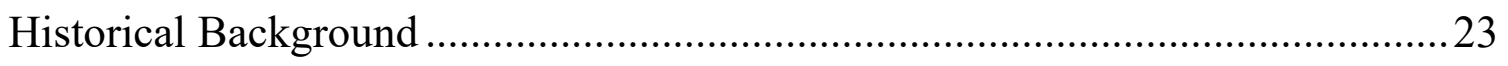

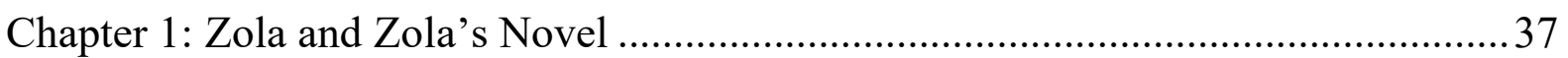

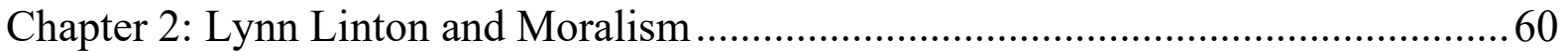

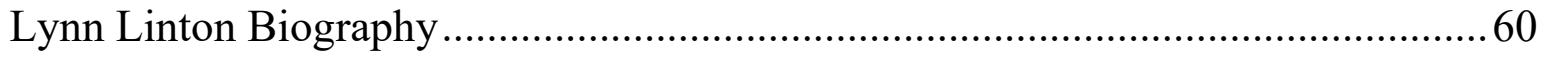

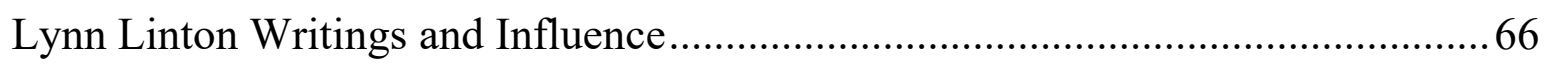

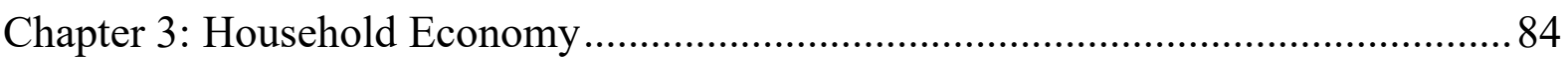

The Role of Women and Household Management ............................................ 84

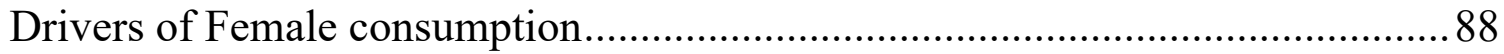

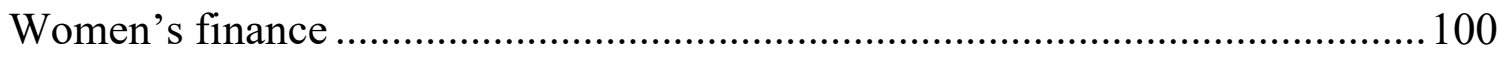

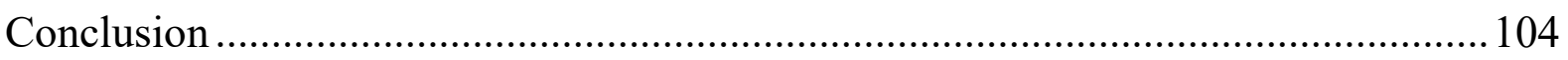

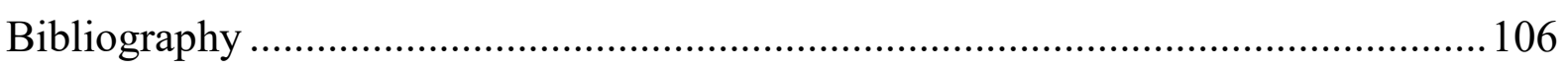




\section{Introduction}

The purpose of this thesis is to show how The Ladies Paradise by Émile Zola, first published in English in 1883, was perceived by the late Victorian public and how it intervened in and compelled political economic discussions at the time. I argue that The Ladies Paradise is a political economic text and its reception gives us insight into how heated discussions about the political economy were going on in discursive spaces outside of texts that we might consider to be part of the political economic canon (a canon concerned with both political economy and critiques of political economy) for the period, such as those by Karl Marx and Walter Bagehot. Throughout my thesis I will argue that moralist arguments, produced by late-Victorian conservative thinkers, focused on the world of literature for the purpose of dissuading the public from engaging in sensual capitalist practices. In particular I will argue that many people in late Victorian England were deeply troubled by representations and realities of female-dominated consumerism, especially when it was more sensual and pleasure-oriented, and how that might grant women certain liberties and centrality within the political economy. My research throughout this thesis is important in aiding our understanding of how literature is an important source when it comes to understanding the political economy of the past.

The scope of my paper will, for the majority, be concerned with 1880-1890s England, though I will go outside of this in my historical background section in order to outline the events and social practices which were in place from the mid-nineteenth century, leading up to the 1880s. My purpose for this specific focus on 1880-1890 Victorian England can best be summed up in three reasons. Firstly, The Ladies Paradise, was published in 1883. Considering that I am researching the reception of this novel, I have to look at the $1880 \mathrm{~s}$ 
specifically. Secondly, the period from the 1880 s to 1890 s had a large discussion about literature and economy taking place, which was very politically charged. It is a time period during which conservative moralist writers such as Lynn Linton were prolific and popular, and they were pushing against unbridled capitalism particularly in the consumption sphere. Lastly, critiques and scandals surrounding Zola and his work during this time period not only added to his popularity but also, when studied in detail, offer unparalleled insight into what, exactly, the late Victorians were afraid of in terms of what I will call sensual capitalism. The definition of sensual capitalism which I will apply throughout my paper, as I will explain in more detail later in my theory section, is based off of Zola's application and discussion of the senses. This type of sensual capitalism concerns itself with the stimulation of consumer senses for the purpose of enticing consumers to engage in pleasurable and desire-driven consumption, which Zola and Marx saw as propelling the capitalist system. In critiquing capitalism, Zola came to use the terms sensual capitalism and sensory pleasure synonymously when talking about consumption, which he saw as driven by the senses and desire. Whilst my paper occasionally considers physical commodities and their purchase by middle and working class women, this is not the only type of consumption I will be analyzing. Consumption, broadly, as in the taking in of something through the senses -touch, smell, taste, hearing and visual -- will also be addressed. Consumption driven by the senses as described by Zola and newspaper articles writing about nineteenth century department stores at the time overlap in their descriptions of consumption where the sensual and purchasing realm are concerned. This is why the terms "consumption" and "purchase" will be used synonymously throughout this paper.

This introduction will discuss the basic underlying theories for my work, which include Bagehot's definition of Victorian understanding of political economy followed by Marx's definition of political economy. I will then analyse and compare the two for the 
purpose of identifying where they are similar and, most importantly, what they both underemphasize: namely, the consumption side of the economy. This vagueness in their analysis left hazy the realm of consumer experience which writers such as Zola and his critics sought to make more concrete, as I will address in later chapters. After analysing the theories presented by Bagehot and Marx, I will then discuss sensual capitalism and consumption theories. These are useful theories that will aid me in probing the dead angles assumed by Bagehot and Marx.

Following my theoretical chapter will be my historical section. Here I will underline some of the key historical events which were taking place during and before the 1880 s that put pressure on how Zola, his critics, and society in general understood political economy. In this chapter I will discuss important events such as the Great Exhibition and the "Long Depression," for the purpose of juxtaposing the realities of Victorian lives at the time to fiction. This contrast in events will also play a key part in establishing an understanding of the receptive audience of The Ladies Paradise, and who the entire sensual capitalist argument concerned. In the concluding sections of this chapter, I will also briefly highlight the changes to middle class women's lives and the increased liberties that these women gained from the Great Exhibition and department stores alike. In doing so, I will discuss themes of: women's rights, spatial dimensions, literature, consumption, and female employment.

Chapter 1 will largely consist of Zola's biography and an analysis of the reception of Zola's novel in England. Here I will make my argument that Zola was a highly influential and popular writer, whom many conservative writers criticized for "prostituting" literature. This chapter will be a foundation upon which I will establish Zola's vision of political economy for the following chapters. 
Chapter 2 will discuss one of Zola's contemporary critics, conservative anti-feminist writer Lynn Linton. Her character and her enigmatic politics enabled her to become particularly important in the moralist arguments. In the latter sections of this chapter I will compare and contrast sections from Linton's writings and The Ladies Paradise, in order to address some of the underlying similarities and differences between the two. The purpose of this chapter is to present Linton's moralist arguments against Zola and The Ladies Paradise and in so doing expose how theirs was not only a debate about literary aesthetics but political economy. In this chapter I will also begin establishing why some conservatives were wary of middle class women and their role in consumer society.

Chapters 3 will show how this world of literature and literary criticism both came out of and sought to intervene in the material realities of consumption: women's household economies as the drivers of female consumption and participation in the wider world of liberalism. This section will be most crucial in proving my overarching argument regarding the late Victorians' hesitancy to accept sensual capitalism and the push against women's political as well as economic enfranchisement.

Without a fuller understanding of political economy, we fail to understand how matters about consumption could drive politics, culture, and society, and instead tend to view consumerism as an inevitable outcome of liberal conditions of production. If we can appreciate the contingencies alive in consumption, and consumption as mutually constitutive with discussions and realities of political economy in the time period, not only do middle and lower class women become more central to the story as they rightly were but the circumstances of female enfranchisement and the political upheavals of the twentieth century, such as the turn towards Conservatism from 1951-64, which social historian Ina Zweiniger- 
Bargielowska has argued happened because women overwhelmingly voted against extending the ration under a Labour government, can be seen to develop over a longer duration. ${ }^{1}$

\section{Theory}

Walter Bagehot's status as a widely-read political economist in the nineteenth century recommends his theory as representative of a dominant strain of "political economic thought" in the period. Before I go into his theory, it is necessary to introduce him and establish his importance and influence during the Victorian era. For this I will refer to a biography on Bagehot written by American writer and publisher, James Grant.

Walter Bagehot was born in 1826 in Somerset, England, and was the second child in a family of bankers. Bagehot's father, Thomas Watson Bagehot, was a director and vice chairman of Stuckey's Bank, as well as the husband of Edith Stuckey. When Bagehot was nine he attended classes at the Langport Grammar School and at the age of thirteen, “...his parents enrolled him in Bristol College, which was founded eight years earlier by Unitarian freethinkers." ${ }^{2}$ This went along with his family's beliefs as they were also Unitarian thinkers. It is exactly for this reason that despite his academic success, Bagehot never attended Oxford or Cambridge -- institutions which required "entering students to subscribe to the tenets of the established church." ${ }^{3}$ Instead in 1842 Bagehot commenced his studies in mathematics at University College of London. In 1848, he continued his studies and successfully earned a master's degree in moral philosophy, with the full intention of pursuing a career in law. After a few years in the industry, Bagehot quickly realized that this was not his calling and instead

\footnotetext{
${ }^{1}$ Here I refer to Ina Zweiniger-Bargielowska's important work Austerity in Britain: Rationing, Controls and Consumption, 1939-1955, (Oxford: Oxford University Press, 2000), in which she showed how women of all class backgrounds supported the Conservative party in 1951 largely because that Party promised to end the ration while the Labour Party did not. It is the only time in British history that a "woman's vote" can be discerned and the vote hinged not on what people think of as classic "women's issues" like reproductive rights but consumerism, instead.

${ }^{2}$ James Grant, Bagehot: The Life and Times of the Greatest Victorian, Illustrated Edition (New York: W. W. Norton \& Company, 2019), 31.

${ }^{3}$ Grant, 35 .
} 
returned to work with his father in the family banking and shipping business. Bagehot was very successful for a number of years, before turning to journalism and politics.

Change and success came to Bagehot in 1855 when he founded the National Review with Richard Holt Hutton, and again in 1858 when he married Elizabeth Wilson, who was the daughter of James Wilson, the founder of The Economist, a magazine devoted to liberal ideology and a popular outlet for political economic discussion. Bagehot served as an editor for The Economist for 17 years, during which he published numerous books and articles on English politics, until his death in 1877. Some of Bagehot's most prominent works include The English Constitution (1867), Physics and Politics (1872), and Lombard Street: A Description of the Money Market (1873). Although it is unclear as to how wide the readership of Bagehot's writings was, one thing is certain: Bagehot's political texts were widely recognized and accepted among English policy makers at the time. ${ }^{4}$ By his death, Bagehot was recognized as being a highly famous and influential political writer who wrote about radical libertarianism in economic policy and, ironically, the need to expand economic criteria by including cultural and social factors. ${ }^{5}$

Whilst most of Bagehot's writings were centered on parliaments, English monarchy and imperialism, one book in particular has become a classic of political economy: The Postulates of the English Political Economy (1885). As clearly addressed by Alfred Marshall, editor and transcriber of the book, Bagehot's intention was to make a landmark in the history of economics by separating the use of the older less understood, or Ricardian, economic reasoning from "political economy" and reworking them. ${ }^{6}$ Unfortunately, Bagehot died before completing the book and "...he did not complete more than the examination of two of

\footnotetext{
${ }^{4}$ Grant, Bagehot.

${ }^{5}$ Grant, 40.

${ }^{6}$ Walter Bagehot, The Postulates of the English Political Economy (New York, N.Y.: Cosimo Classics, 2006), 4.
} 
their postulates - the transferability of labour and capital." "7 Despite this, I would argue that this particular work is the best representation of Victorian political economic thinking where production and consumption are concerned. Evidence for this can be found in The Postulates of the English Political Economy, where Bagehot applies Smith's ideas to discuss trade and commodities, along with his own discussion on commerce abroad.

Bagehot argues that it is important to understand where British political economy began. To do this he applies a definition of political economy which is heavily based on Adam Smith and James Steuart. Similarly to Smith, Bagehot and other economists of the time generally believed that a political economy revolved around a commodity being sold on the market and the labor that was employed to make the commodity useful and valuable. ${ }^{8}$ Bagehot did not clearly define what political economy was, which is why it is difficult to discern an exact definition. A few things are certain, however. For Bagehot, English political economy essentially revolved around business transactions, the sale and production of commodities, laissez-faire market policies and the success of the British Empire outside of England.

In many ways Bagehot's understanding of political economy is similar to his contemporary, Karl Marx. For Marx the commodity plays a central part of the capitalist mode of production and it is why Marx, in his book Capital, presented the commodity first, followed by sections on exchange value and value. Marx discovered that the entire capitalist mode of production relied on commodities: "the wealth of societies in which the capitalist mode of production prevails appears as an immense collection of commodities", Marx declared. ${ }^{9}$ In establishing what the core of political economy is, it is easier to determine how the capitalist system works. Both Bagehot and Marx agree in their understanding that the

\footnotetext{
${ }^{7}$ Bagehot, 5.

${ }^{8}$ Bagehot, 5.

${ }^{9}$ Karl Marx, Ben Fowkes, and David Fernbach, Capital: A Critique of Political Economy, V. 1: Penguin Classics (London; New York, N.Y: Penguin Books in association with New Left Review, 1981), 125.
} 
commodity is at the core of a capitalist system. Where Bagehot's understanding of political economy falls short is in him not defining and establishing what a commodity is, and how it is valued in a market.

Instead Marx's theory can be applied here to fill the gap. Marx's definition of a commodity is, "an external object, a thing which through its qualities satisfies human needs of whatever kind." ${ }^{10}$ Marx, however, was not interested in studying commodities to show how or why they might be useful to humans, but rather the fact that the commodity must be a useful good of some sort, or else it would not have been produced in the first place. It is at this point that the theory of use value and its subsumption by value is introduced: "The usefulness of a thing makes it a use-value" and it is "only realized... in use or in consumption." ${ }^{11}$ Objects which are created for oneself despite being useful are not considered as commodities by Marx's definition. This is because, "In order to produce the latter, he must not only produce use-values, but use-values for others, social use-values."12 Put differently, a commodity must be a product of social labor, and must have a use which is realized through its use or consumption.

Marx then takes this discussion of commodities and use-values further by discussing exchange value of commodities through trades and markets. "Exchange-value appears first of all as the quantitative relation, the proportion, in which use-values of one kind exchange for use-values of another kind."13 Though Marx utilizes the concept of exchange-value to denote "price," exchange-value itself is simply a manifestation or "form" of the most substantive relation of capitalism which is value. In his discussion of the commodity, Marx's intention is to unfold all the categories of capital in their logical sequence. As Marx puts it, the

\footnotetext{
${ }^{10}$ Karl Marx, Ben Fowkes, and David Fernbach, Capital: A Critique of Political Economy, V. 1: Penguin Classics (London; New York, N.Y: Penguin Books in association with New Left Review, 1981), 125.

${ }^{11}$ Marx, Fowkes, and Fernbach, 126.

12 Marx, Fowkes, and Fernbach, 131.

${ }^{13}$ Marx, Fowkes, and Fernbach, 126.
} 
commodity is dealt with not as it appears at various points in human history, rather it is "...the commodity as the universally necessary social form of the product [that] can only emerge as the consequence of the capitalist mode of production." 14

What Marx is writing about in the early chapter of Capital is the capitalist mode of production. Consumption, which is a sub component of the capitalist system alongside production is rarely mentioned by Marx. It is unfair to claim that Marx didn't care about consumption at all or that he thought it to be irrelevant and separate from the capitalist system. Instead he viewed it "negatively because it led to alienation among people" which Marx addresses when talking about commodity fetishism. ${ }^{15}$ I will define the term commodity fetishism later in this chapter when I discuss its relevance to sensual capitalism and Zola. For Marx human consciousness and character is linked through consumption patterns, "the more you consume, the less human you are." ${ }^{, 16}$ As Marx explains this is because in capitalist societies workers sell their labour power which is used to produce commodities. These commodities over which they have no ownership are then sold on the market for their exchange value. The exchange value or instead "price" determines to an extent what commodities are produced "as well as how goods are distributed." ${ }^{17}$ Commodities which possess the highest exchange values in relation to cost of production are the commodities which will be favoured in capitalist production. One of the costs incurred in the production stage is labour cost. How much labour power the workers have will determine the price of the labour they offer as well as their purchasing power when it comes to the commodities they produce. For this reason in capitalist societies "relationships between people are determined by the prices of commodities" and human labour. ${ }^{18}$ This application of commodity fetishism

\footnotetext{
${ }^{14}$ Marx, Fowkes, and Fernbach, 949.

15 Scott G. McNall, 'You Are What You Eat: Some Thoughts on Consumption and Marxist Class Theory', MidAmerican Review of Sociology 14, no. 1/2 (1990): 45-52.

${ }^{16} \mathrm{McNall}, 45$.

${ }^{17} \mathrm{McNa}$ c 45.

${ }^{18}$ McNall, 46.
} 
will differ slightly from the sensual capitalist one in which labour is considered differently. I will expand upon this discussion later in this chapter when I discuss sensual capitalism.

Marx viewed consumerism through a negative lens predicated upon underpaid wagelabour and commodity fetishism, a fundamentally irrational condition, essential for a capitalist system to survive. I argue that although the importance of production, labour, and especially the rise of wage-labour was most definitely a driver of Victorian capitalism, this took place within a context of mutually constitutive development in consumerism and commodification that was, and has been, too quickly dismissed by standard critics of political economy. Consumption and consumer practice were equally as important in the production of commodities. By focusing on consumption and how critiques of it played out in literary realms more likely to be engaged with by women, I analyze a whole other dimension of critique of nineteenth century capitalism and department stores that Marx and Bagehot did not make sustained reference to.

Going back to my discussion of Bagehot and how he compares to Marx's understanding of political economy, these two writers overlap in that for them the economy is operated by markets which offer a place of exchange for commodities. This understanding of political economy as also coincides with The Ladies Paradise because the department store within the novel is essentially a market place, which engages in the production and sale of commodities. The type of political economy Zola is writing about in the novel, in many ways overlaps with Marx's understanding of political economy. This is particularly the case when I look at commodity fetishisation, use-values, exchange values, and surplus production. These are all examples of theories of political economy from Marx's Capital, which Zola writes about in his novel. Differences occur when Zola engages in the discussion of sensual capitalism, which as I will show later in this chapter, was a branch of political economic theory that Marx in later life distanced himself from. 
Going back to my discussion on Marx's understanding of political economy, Marx's points on commodities representing a business exchange coincides with Bagehot's understanding of political economy, in which markets engage in business transactions. For Bagehot, political economy can be defined "as the science of business, such as business in large productive trading communities." ${ }^{19}$ Going further, Bagehot states that business, "assumes that every man who makes anything, makes it for money, that he always makes that which brings him in most at least cost, and that he will make it in the way that will produce most and spend least; it assumes that every man who buys, buys with his whole heart, and that he who sells, sells with his whole heart, each wanting to gain all possible advantage."20 Despite being clearly focused on business matters, what Bagehot is describing here is akin to a liberal capitalist production system that is little different to Marx's exchange value capitalism. Although the two approach the matter differently, it is undeniable the nineteenthcentury political economy was concerned with the production and sale of commodities. Businesses that produced commodities, did so, in this thinking, "for money" with the assumption that the commodity was valuable and useful, hence the exchange value, which was represented in increased price. Whilst both of these theorists were ultimately writing on the same topic, they both fail to discuss consumption and how consumer interests could affect political economy in manipulative, agential ways, as if just having the commodities available and pricing them accordingly would guarantee consumer uptake.

Up until this point, we encounter a deep discussion from both writers which is centered on the production and sale of commodities, which are valuable or useful, but there is no acknowledgment of consumer desire, agency, culture, changeability, et cetera. This I argue, is one of the greatest limitations in these two theories, in their approach to production

\footnotetext{
${ }^{19}$ Bagehot, The Postulates of the English Political Economy, 8.

${ }^{20}$ Bagehot, 9.
} 
and consumption in a capitalist system. It is also a strong indicator of the ways in which political economy as such was viewed from the Victorians' perspective. Marx clearly indicates in Capital, that "competition and demand determine the aim of capital and which commodities should be produced." ${ }^{21}$ But competition cannot arise from production alone, there has to be an antagonism between another factor: consumption. Bagehot is no different to Marx in this particular sense, despite extensively discussing the export and import of commodities in English free trade, he also does not acknowledge the consumption of or demand for commodities, nor the identity of the consumer.

It is in many ways surprising that Marx was so close to explicating a threedimensional concept of consumption as a counterpart to production, but he never quite fleshed it out. My only possible argument for this is that consumption simply was not a branch of political economy that economic thinkers were concerned with at the time, perhaps because it concerned for the most part the female sex who, as consumers, were assumed to be acting as a result of "natural" or irrational demand and not capable of deeper, rational, somehow more-legitimate motivations like alienation, for example, as Marx sets up worker alienation to be a major ingredient for historical change. After all, as I will show in my later chapters, it was the middle class women who managed the household economies and who were the biggest consumers throughout Victorian England. The political economy that Marx and Bagehot wrote about is the political economy of male workers and business managers, in which the activity of women consumers was either a mindless historical constant or an ancillary reaction to the rise of wage-labour. This explains why there is so little said about middle and lower class women's production, consumption and importance on political economy in both Marx's and Bagehot's works in general. This is a strong limiting factor of

\footnotetext{
${ }^{21}$ Robert Albritton, A Japanese Approach to Stages of Capitalist Development (Basingstoke, Hampshire: Macmillan, 1991), 15.
} 
these two writers, as the consumption of women of all classes, but most particularly the middle class, formed the backbone of the late Victorian political economy and capitalism. Without them, many producers and establishments such as the department stores, would not exist and certainly would not have developed in the ways that they did. As I will discuss in the historical background section, it appears that the store owners and Émile Zola were aware of the centrality of the female consumer to economic processes, to the point where these consumers were particularly sought after and tended to. And yet, in the realm of "high" politics, they were seen as peripheral to the "real" story of production within political economy. It is for this reason in particular that I will argue, real everyday life politics which demonstrate the realities of political economy in the Victorian period, can perhaps best be found in literary writers such as Zola.

Before I move on to my discussion of sensual capitalism and how it can be applied to reconsider the underemphasized areas of Marx's and Bagehot's theories, I will point out one additional point which Bagehot makes in his book. This point in particular concerns itself with the state of politics in England. For Bagehot, “...the position of our Political Economy is not altogether satisfactory. It lies rather dead in the public mind. Not only does it not excite the same interest as formerly, but there is not exactly the same confidence in it. Younger men either do not study it, or do not feel that it comes home to them, and that it matches with their most living ideas." He wrote this in the midst of a liberal crisis, the so-called "Long Depression" that lasted between 1873 and about 1895. I would argue that it was not true that people had become disinterested in discussing political economy, instead it was discussed in a very different way and by very different people than Bagehot saw as significant: novel readers, literary critics, and women's rights activists. To support my argument here, I wish to point to Zola and The Ladies Paradise as an example. On the surface, this novel appears to be no more than a novel about shopping and romance, but under the surface, it is very politically 
charged. Through his novel, Zola encouraged people to discuss topics related to consumption, capitalism and women's agency in ways that felt morally dangerous at the time. Further, as I will show, a large proportion of Zola's readership was constituted by women, more concretely, middle- and upper-class women, who would otherwise not be welcomed in political economic discussions. Zola is, at his core, an example of a literary author who in his works encompassed a strong political agenda or meaning, without being overtly politicized. What this entire point shows is that writers such as Marx and Bagehot were writing about a completely different realm of power relationships that excluded some of the main players in the British economy at the time.

\section{Political Economy of the Senses}

In this section I will discuss sensual capitalism and then three consumption theories in order to analyse how they can be applied to this question of political economic discussion in and about Zola.

Before I begin defining sensual capitalism, it is important to note that Marx initially wrote about sensual capitalism in his earlier works, such as in his Economic and Philosophic Manuscripts of 1844. In his later works however such as Capital, Marx appears to distance himself from sensual capitalism. Due to this, the historical background and origins of sensual capitalism are somewhat disjointed. Other academics such as Bryan Nelson and David Howes took to the task of analysing Marx's understanding of sensual capitalism, which is why this following section will be split into three different parts. I will first analyse Marx's understanding of sensual capitalism as presented by Nelson. From there, I will briefly expound on Nelson's and Howe's interpretation of Marx's sensual capitalism. Lastly, I will briefly compare and contrast these approaches to understanding sensual capitalism, for the purpose of determining my own understanding and definition of sensual capitalism, which 
will be applied in this thesis. At the end of the section I will introduce the three consumption theories which will be used in Chapter 3. The purpose of defining sensual capitalism and applicable consumption theories in this section is to develop a stronger understanding of the consumption taking place in The Ladies Paradise and the late Victorian department stores. This theoretical perspective will also enable me to interpret the arguments Linton and Zola are having in the literary sphere alongside the political economy ideals of the time.

To begin, as I have stated previously, despite Marx's theoretical gaps in Capital in regards to the senses and consumption, Marx originally wrote about sensory capitalism in his manuscripts. In his earlier writings, Marx was still at large influenced by materialist philosopher Ludwig Feuerbach, and utopianist writer Charles Fourier, thereby shaping Marx's earlier opinions regarding capitalism and the importance of the senses. For Marx at the time, the five principal human senses were a representation of humanity's progressive development across the entire history of the world..$^{22}$ Fourier initially stated that,

"... Societies could be judged according to how well they gratified and developed the senses of their members... if sensory pleasures were to be made more available most people would be unable to appreciate them as their senses remained brutish and undeveloped. These sensory ills, according to Fourier, were the result of a society obsessed with the accumulation of personal wealth to the detriment of the general well-being." 23

Here Fourier builds on the simple five human senses principal by bringing in factors such as gratification and sensual pleasure, whilst at length determining that the senses are something that need to be cultivated, developed and understood. Considering that Marx was strongly influenced by Fourier's writings there is little surprise that we can see hints of Fourier's interpretation of the senses in Marx's earlier writings. In these earlier writings Marx wrote about how, "Man is a corporeal, living, real, sensuous, objective being... sensuous objects as

\footnotetext{
${ }^{22}$ Bryan Nelson, 'Politics of the Senses: Karl Marx and Empirical Subjectivity', Subjectivity 4, no. 4 (1 December 2011): 395-412, https://doi.org/10.1057/sub.2011.19.

${ }^{23}$ David Howes, Sensual Relations Engaging the Senses in Culture and Social Theory (Ann Arbor: University of Michigan Press, 2003), 206.
} 
the object of his being and of his vital expression..." 24 In other words human kind are sensuous beings who express themselves and their sensual experiences through the objects of our labour. Marx expounds on this further by stating that, whenever human kind engages in the outside world through the activation of our biological senses (such as sight, smell, touch etc...), we appropriate the object of our focus and manifest our experiences within the object. Going further, as "the senses become the active expression of particular historical conditions; they embody and reflect, as it were, the social character of their appropriated objects." ${ }^{25}$ In other words commodities embody the human labour that manifests within the object as well as social and historical conditions at the time.

This juxtaposes with Marx's Capital, in which Marx instead takes the stance that, at the point of exchange that the commodity loses all of its sensuousness and becomes "an atomless ghost." ${ }^{26}$ It loses all of its mysterious qualities and becomes simply put, an object. It is an object within which labour has of course manifested, nevertheless any of the sensual experiences and expressions of historical conditions or culture that went into the production of the commodity, which gave it its mysterious qualities, vanish. This Marx argues is particularly the case with commodities that are fetishised. As proposed by Marx, in a capitalist society "fetishism attaches itself to the products of labour as soon as they are produced as commodities, and is therefore inseparable from the production of commodities. ${ }^{27}$ Marx turns to fetishism to explain the mysterious character of commodities.

This application of fetishism varies quite little from the one I offered earlier in this chapter. Instead of focusing on wage labour the focus is put on the mystifying qualities which are attached to a commodity after they are produced. These mystifying qualities can influence

\footnotetext{
${ }^{24}$ Nelson, 'Politics of the Senses', 405.

${ }^{25}$ Nelson, 409.

${ }^{26}$ Howes, Sensual Relations Engaging the Senses in Culture and Social Theory.

${ }^{27}$ Marx, Fowkes, and Fernbach, Capital, 165.
} 
consumption and desire which is why this application of commodity fetishism is most relevant when looking at sensual capitalism. Considering that Marx proposed both of these applications of commodity fetishism it is possible to conclude that Marx himself was aware of the complex nature of commodities and human labour.

By itself a commodity is a simple good in which human labour has manifested and it remains a simple commodity for as long as its use-value is clear. What Marx doesn't say in Capital regarding commodity fetishisim is why, or rather how a commodity earns its mystifying qualities for which it is fetishised. If we were to apply Fourier's and Marx's earlier understanding of sensual capitalism, then it is possible to argue that commodities earn their mystifying qualities from the social, cultural and historical relationships which went into the production of the commodity.

Instead, in Capital, Marx adopts a different view, in which the commodity, "changes into a thing which transcends sensuousness" through its exchange. ${ }^{28}$ To further explain, Marx in Capital is concerned with the specific point at which the commodity transitions from being an object created through human labour, to the very point where it comes into contact with money, which is the universal form of exchange. It is during this phase that Marx argues, people in a capitalist society treat the commodity as a value independent from the real labour which was required to produce the commodity in the first place. Whilst Marx admits the importance of the manifestation of labour within the production of a commodity, he fails to acknowledge the sensual qualities of the commodity earned through historical and cultural relationships and transitions.

Howes argues that ultimately Marx's theory of value is incomplete because it does not include sign-value. Sign-value can be understood in simple terms as sensory and social

\footnotetext{
${ }^{28}$ Marx, Fowkes, and Fernbach, Capital, 163.
} 
relations which are embodied within commodities, thereby acknowledging the cultural and social relations of commodities to people, beyond purely their exchange values. Howes criticises Marx for choosing to not question or address differences between commodities and their cultural values in Capital, because a sign-value of a commodity can expose the social relations which are concealed within a commodity. This is why when Marx abandons his theory of sensual capitalism in Capital and attempts to engage with commodities in a purely objective manner, he is ultimately disregarding the historical, cultural and social relationships that went into the creation of the commodity. This brings us to the conclusion that commodities cannot and should not be stripped of their interior qualities and considered purely objectively, as Marx attempts to do in Capital.

For Marx the activation of the senses are inhibited by capitalism through the conditions of private property accumulation, in which the acquisition of wealth and capital are more important than sensual stimulation. The senses under capitalism are no longer activated to their full potential and are instead altered in the ways in which they are used, through the organised production of experiences. For Marx, "capitalism represents the corruption of the senses, the deterioration of their social quality, their inability to experience in a human way. The senses are composed according to the experience of private property... and is reduced to a one-dimensional sense of possession..."29 In capitalism human kind is more concerned with the accumulation of private property, this is why the senses become estranged. It is for this reason Marx argues that, “...not even among the bourgeoisie are the senses fulfilled." ${ }^{30}$ Precisely because capital accumulation was desired above all else. This is where I would instead take Nelson's perspective on sensual capitalism, in which it is important that human experience should not be limited to the offerings of capital and that

\footnotetext{
${ }^{29}$ Nelson, 'Politics of the Senses', 409.

${ }^{30}$ Howes, Sensual Relations Engaging the Senses in Culture and Social Theory, 206.
} 
sensual emancipation can only be achieved when there is supersession of capitalist ideals. ${ }^{31}$ It is only when we engage in collective, social exchanges that engage with our senses and embody our experiences without the limitations of capitalism, that human kind can truly be sensually liberated.

Marx's positioning that not even among the bourgeoisie are the senses fulfilled is very provocative when we consider late nineteenth-century department store consumption. The department store is an example in which capitalism does in fact produce senses, sensual experience, and at times even sensual fulfilment. But it does this in a particular way. Sensual fulfilment through capitalist consumption is short lived and at its core expertly crafted, for the purpose of capital accumulation, which is different to the type of sensuousness Marx was writing about, which may help explain why for Marx, capitalism does not produce the senses in an authentic way. My stance on this matter is that capitalism produces the senses in a mediated and purposeful way which supports and enables the capitalist system, which is why when Nelson writes about liberation of the senses, his is essentially discussing the liberation of the senses from the ways in which they are activated and manipulated by capitalism.

David Howes takes a slightly different approach to analysing and applying Marx's understanding of sensual capitalism. For Howes, sensual capitalism is most evident in its exploitation in consumerist markets. This consumerist type of sensual capitalism is most synonymous with what was taking place in late-nineteenth century department stores and within The Ladies Paradise. This is why Howes's analysis of sensual capitalism must be applied alongside Marx. Howes, similarly to early Marx and Fourier, argues that it is impossible to separate the object from its cultural ties: "One of the most important ways in which cultural categories are substantiated is through the material objects of a culture ...."32

\footnotetext{
${ }^{31}$ Nelson, 'Politics of the Senses', 410.

${ }^{32}$ Howes, Sensual Relations Engaging the Senses in Culture and Social Theory.
} 
Commodities, Howes argues, act as blueprints of social culture which embody the labour used to produce the commodities.

The difference between Marx's and Howes's interpretation arises in Howes's interpretation of the senses. Marx ultimately took the stance of a bourgeois moralist later in life which strongly impacted the ways in which he approached and considered the human senses. For Marx the human senses of taste, touch and smell were considered as being "primitive", versus sight and hearing which was comparatively more "civilized". ${ }^{33}$ History of the Senses scholar Constance Classen has argued that this hierarchy of the senses was very gendered, with the primitive senses being associated with femininity, women, and subjectivity and civilized senses being associated with masculinity, men, and objectivity. ${ }^{34}$ Marx was in many ways not interested in the so called "primitive" senses, which would explain their absence in his writings. Howes clearly points out that whilst Marx was ready for a "social revolution, Marx was evidently not ready for a sensory revolution" 35 , which I argue is very typical of late Victorian thought in England. It is easy to see why women engaging in sensual consumption associated with the "primitive" senses were considered to be uncultured and uncivilized. This regression into barbaric ways through engagement with sensual consumption is one of the reasons why, as I will show later, morality was emphasised in late Victorian literature, shopping guides and newspapers. Marx essentially produced a very gendered view of the senses without truly acknowledging the cultural and social drivers behind it.

For Howes the principal human senses do not hold quite as negative a connotation as Marx's. Howes writes that it is in capitalist consumerism that we see the senses being

\footnotetext{
${ }^{33}$ Howes.

${ }^{34}$ Constance Classen, The Deepest Sense: The Cultural History of Touch, (Urbana: University of Illinois Press, 2012), 10, 20-21, 191-6.

${ }^{35}$ Howes, Sensual Relations Engaging the Senses in Culture and Social Theory.
} 
important and in many ways exploited. In consumerist capitalism, it is capitalism's goal to engage in as many human senses as possible in its seduction of the consumer. The commodity must, depending on the kind of product being sold, be reinforced by the right feel, the right scent, the right sound and the right taste. ${ }^{36}$ The purpose of this is to activate the human senses and incite feelings of pleasure and desire from a consumer, which will in the end drive consumption. This is the type of sensual capitalism that we see most commonly take place in The Ladies Paradise and late Victorian department stores. More on the ways in which capitalism engages with the consumer senses later in my paper.

The issue here is that the senses are manipulated and exploited by capitalism and, in a context of political economy, liberalism. In other words the desires and wants are expertly fabricated by capitalism and are not a good representation of the culture and social relationships that went into the creation of the commodity and sensual stimulation through its consumption. Howes argues that sensual capitalism "uses services as the stage and goods as props for creating "experiences" that are as stimulating for the consumer as they are memorable." ${ }^{37}$ The Great Exhibition is an example of an event during which the senses of the Victorians were stimulated in order to create a memorable experiences. The department stores are similar in this regard too with their extravagant window and shop displays geared towards awakening and exciting the female consumer's senses.

Howes's interpretation of sensual capitalism is in many ways in sync with the type of sensual capitalism Zola is writing about in The Ladies Paradise in that consumption transcends the type of rationality Marx was writing about, and instead becomes irrational and sensual. As Zola illustrates in many scenes throughout the novel, consumer senses were stimulated within the department store, thereby inducing the desire to consume despite all

\footnotetext{
${ }^{36}$ Howes.

${ }^{37}$ Howes.
} 
rationale. It is this activation of the senses for the purpose of driving consumption through sensual pleasures and experiences, that is applied by Zola in his novel, and is what will constitute as my definition of sensual capitalism throughout this paper.

Whilst I have made it clear that consumption was partially driven by sensual capitalism, this was not the only driver, as I will show in chapter three, when I discuss consumption theories. Middle class women, who were at the core of household economies and consumption, did not only consume due to sensual reasons. There were also many legitimate and socially acceptable explanations for why these women consumed commodities and space. Some of these include but are not limited to imitation, emulation, and jealousy. A few of these reasons, coincide with scenes from The Ladies Paradise, and the consumption theorists I will discuss. In chapter three, I will be applying consumption theories from three theorists in particular. Theories of: consumption for pleasure by Colin Campbell, emulation and conspicuous consumption by Thorstein Veblen and consumption as a means of solidifying class by Pierre Bourdieu, are the theories which I will be applying. The purpose for considering consumption theories in this paper is to show that: 1) there were many drivers of female consumption, which popular political economy and conservative writers were not writing about, and 2) there were often legitimate cultural and class embedded reasons for why these women consumed the way they did, which political economy and conservative writers at the time were not discussing, but Zola to an extent was. Further, these theories will help me establish The Ladies Paradise, as a political economic text because it discusses political economy in ways which were more concrete and relevant to the inner workings of department stores, consumption and women. Before doing so, it is necessary for me to layout the historical events surrounding the 1880's-1890's, starting with the cyclical depression. 


\section{Historical Background}

Cyclical Depression

During the mid-late Victorian era there were two notable economic events which took place: the rise of cyclical depression and more importantly the Great Depression. These two major events are in stark contrast with the department store culture Zola wrote about and the Great Exhibition, which took place in the 1850s but became a touchstone of Victorian consumerism.

As Gareth Stedman Jones writes in Outcast London, many of the working and lower middle classes were frequently affected by cyclical depression and unemployment, particularly in large cities. Rapid development and the spread of the industrial revolution earlier in the century meant that large cities became the center of all market transactions in England. Old establishments which applied pre-industrial revolution techniques in their production process were under critical threat, as they could not keep up with the production speed of industrialized enterprises ${ }^{38}$ Further, unlike industries which were concerned with the production of raw materials, which saw stable demand no matter the time of the year, those in the finishing industries were not so fortunate. Due to increased competition and the decrease of commodity prices as a result of increased production, many businesses felt that they could not offer stable employment for their workers. ${ }^{39}$ To make matters worse, the demand for finished commodities on the market fluctuated depending on the season or time of the year. To counteract this financial burden, some employers hired their workers on short term employment basis, whilst others kept the most skilled workers and laid off the rest until demand rose again. ${ }^{40}$ Workers who were laid off and had little opportunity to prepare in

\footnotetext{
${ }^{38}$ Gareth Stedman Jones, Outcast London: A Study in the Relationship Between Classes in Victorian Society (Verso Books, 2014).

39 Jones, 35 .

${ }^{40}$ Jones, Outcast London, 39.
} 
advance for the financial struggles they would face during their periods of unemployment, often found themselves in very poor financial situations, with some even succumbing to poverty. This cycle of employment and unemployment continued throughout much of the mid-late nineteenth century. Thus, this time period has become associated with the establishment of seasonal workers and cyclical depression. This brief observation of worker employment during the nineteenth century, will become an important comparative factor when I discuss the events and success of the Great Exhibition later in this chapter.

\section{The Great Depression}

Aside from its effect on the working and middle classes, the cyclical depression also alluded to the issues behind the causes of the Great Depression, which was arguably an even more impactful event on the English political economy and working classes. The Great Depression, otherwise also known as the Long Depression, occurred approximately from 1873 to 1896 , and impacted the lower and middle classes the hardest. On the surface, the cause of the Great Depression was a result of drastic fall in grain prices, due to increased American production of grain in the 1870s. But beyond that, the Great Depression was evidence of the first human-caused depression driven by laissez-faire liberal capitalism. This caused serious reflection on the benefits of liberalism and a questioning of the established truths of political economic thought. The causes of the Great Depression can be attributed according to their long term and short-term impacts.

In the short term, the cause of the Great Depression was, "tampering with the currency, debasing the gold standard, and adoption of protective duties." ${ }^{41}$ In order to combat the falling prices, capitalist manufacturers sought to look to new ways to increase and

\footnotetext{
${ }^{41}$ T. W. Fletcher, 'The Great Depression of English Agriculture 1873-1896', The Economic History Review 13, no. 3 (1961): 417-32, https://doi.org/10.1111/j.1468-0289.1961.tb02128.x.
} 
guarantee the demand of their products. Some manufacturers did this by taking part in, "industrial combination, price-fixing agreements, trade campaigns, cartel quotas..." ${ }^{42}$ The tampering of the currency in order to combat changes in prices of goods on the market, eventually led England into a currency crisis, which sparked the beginning stages of the depression.

In the long term, the depression was perpetuated and caused by over production and under consumption of commodities. Due to the success of the industrial revolution which is dated back to mid-eighteenth century, England engaged in increased production of commodities. ${ }^{43}$ However, despite this over production, there was significantly less consumption. One of the reasons for this, as I will argue later in my paper was partially because, Victorians opposed to women's rights, refused to acknowledge that women could support the scale of nineteenth century production by consuming.

Instead, to the effects of keeping middle class women out of the public sphere, politics and sensual capitalism, conservative arguments condemned women's sensuous consumption as being immoral. Aside from this, the issue of under consumption also arose because many politicians and economists at the time, similarly to Bagehot and Marx, refused to acknowledge the importance and necessity of consumption. One of the few ways by which England could have gotten itself out of an economic depression was by consuming more. But this would impose a threat to the patriarchal society and necessitate acknowledging women as having rights in the public sphere. Instead England averted this issue with a temporary fix by taking "control of overseas markets through imperial expansion."

As I have already started to show, the issues of English political economy in the late eighteenth and nineteenth century are partially a result of the patriarchy and women's rights.

\footnotetext{
42 Peter Gurney, The Making of Consumer Culture in Modern Britain (Bloomsbury Publishing, 2017$), 73$.

${ }^{43}$ P. J. Cain and A. G. Hopkins, British Imperialism: 1688-2015 (Routledge, 2016).

${ }^{44}$ Gurney, The Making of Consumer Culture in Modern Britain, 73.
} 
As historian Antoinette Burton writes in her book and as I will explain in more detail in Chapter 2, organized women's rights movements “in Britain emerged in the context of Victorian and Edwardian imperialism" as well as during the cyclical and Great Depressions. ${ }^{45}$ The women's rights movement was largely imbedded in the social, economic and political challenges which were taking place at the time, which is why they cannot be disregarded, as the popular economists and politicians did at the time. The reaction to this economic struggle and conflicting need for increased consumption in a society where there is surplus production and struggle to understand women's rights in public consuming spheres, is most clearly illustrated through novels such as Zola's The Ladies Paradise. Which is why am I arguing that literary novels can and should serve as political economic texts when studying the history of political economy.

\section{The Great Exhibition}

Contrasting against the events and struggles of the cyclical and Great Depressions, there was one event that set the tone for popular ideas about consumption in the 1850s: the Great Exhibition. Unlike the Great Depression which was accepted by the Victorians with pessimism and uncertainty, the Great Exhibition exuded optimism and celebration of liberalism, capitalism, and surplus production.

The Great Exhibition was a significant event for many reasons, but one of them was associated with the influence in establishing department store culture in England. There were smaller department stores across England from at least the eighteenth century but it is 1851 that solidified this market form's future. As proposed by Peter Gurney, a department store "is a large retail store with four or more separate departments under one roof selling different

\footnotetext{
${ }^{45}$ Antoinette M. Burton, Burdens of History: British Feminists, Indian Women, and Imperial Culture, $1865-$ 1915 (Chapel Hill: University of North Carolina Press, 1994).
} 
goods, including either women's or children's wear..."46 He goes on, "Widely known by the 1840 s and 1850s as 'emporiums', it is the large London drapery shops... which can properly be regarded as proto-department stores... Many had numerous departments under the same roof and catered for men, women and children." ${ }^{47}$ Likewise during the early nineteenth century, local markets and bazaars were also seen to be expanding their merchandise, thereby growing in both size and sales. An important distinction to be made here is that whilst the middle and upper classes tended to shop at proto-department stores, the lower classes took their business to local markets and co-operatives. This will be an important distinction to keep in mind when discussing the readership of The Ladies Paradise, and in determining who the predominant customers of popular department stores were. Despite the increase in consumption and production of commodities through pre-1851 forms of department stores, there was an aura of caution and thrift. It is only in during the mid-late nineteenth century that we see consumption culture in England taking on a form of consumption which is most comparable to modern consumption. A large catalyst in this change, was driven by The Great Exhibition.

Held in 1851 in Hyde Park, The Great Exhibition "showcased manufactured goods from across the world..."48 and was housed in what can only be described as a "Crystal Palace which was a monument to consumption..." 49 The Great Exhibition was intended "as a peace conference... which brought together the representatives of thirty-two nations from Europe, America, Africa, and the Far East." ${ }^{, 50}$ Each country present at the exhibition was expected to bring with them manufactured articles from their home countries, which represented their domestic economies and production, "though naturally products of British

\footnotetext{
${ }^{46}$ Gurney, The Making of Consumer Culture in Modern Britain, 87.

${ }^{47}$ Gurney, 23.

${ }^{48}$ Gurney, 28.

49 Thomas Richards, The Commodity Culture of Victorian England: Advertising and Spectacle, 1851-1914 (Stanford University Press, 1990), 3.

${ }^{50}$ Richards, 11.
} 
industry predominated"51 at the exhibition. The Great Exhibition not only celebrated and showcased the commodities of other countries to the English consumers, but it essentially "... displayed England's manufacturing prowess..."to the world. ${ }^{52}$ It was in a way, a celebration of production related achievements amongst all attending countries, as well as reinstating English influence and power.

The Great Exhibition also created an opportunity for the single, "largest display of commodities that had ever been brought together under one roof." ${ }^{\prime 53}$ All of the representatives and commodities were housed in a "...gigantic structure... designed to make ordinary glass look like crystal and the shape of a greenhouse to look like the outline of a palace." ${ }^{, 54}$ The Crystal Palace became a prototype of mid-late nineteenth century department stores due to its structure, and the ease with which it lured people to it. Many editors at the time claimed that department stores following The Great Exhibition, were nothing more than halls of temptation which lured "...unwary women with "ten thousand pretty things." 55 This was primarily because of the transition to glass window panels, which enabled shopkeepers to present their best goods to unsuspecting consumers through elaborate window displays.

Window displays were particularly effective when they incorporated exotic materials, vibrant colors or interesting motifs, thereby engaging the passersby in sensual visual consumption. Talk spread about the luxuriousness of department stores and many commented that they, ““...remember their first visit to a department store and the feeling of wonder and bewilderment it inspired." 56 Whereas another source stated that, "There are few people who have not been struck with the magnificence of the London shop-fronts. They form one of the

\footnotetext{
${ }^{51}$ Gurney, The Making of Consumer Culture in Modern Britain, 28.

52 Erika Diane Rappaport, Shopping for Pleasure: Women in the Making of London's West End (Princeton University Press, 2001), 28.

${ }^{53}$ Richards, The Commodity Culture of Victorian England, 17.

${ }^{54}$ Richards, 3.

${ }^{55}$ Gurney, The Making of Consumer Culture in Modern Britain, 87.

${ }^{56}$ Elaine S. Abelson, When Ladies Go A-Thieving: Middle-Class Shoplifters in the Victorian Department Store (Oxford University Press, 1992), 32.
} 
most prominent indications of the grandeur and wealth of the metropolis." ${ }^{57}$ This is one of the earliest instances of people engaging in sensual consumption in a public sphere, which is why The Great Exhibition was regarded by many as a turning point in English consumption history. Ultimately, the Crystal Palace was and embodiment of modernity and consumption in a very concentrated form. It was an ideal of the nineteenth century and promised a modern and materialistic life for all who could afford it, which was mainly the middle and upper classes. Consumers were encouraged to desire a never-ending accumulation of things and dream of a materialistic construct of a good life. Gurney points out in his book, department stores not only traded in physical commodities, they also traded in dreams. Which is why window displays were so extravagant and exotic.

As Thomas Richards writes in his book, The Commodity Culture of Victorian England: Advertising and Spectacle, the Great Exhibition essentially changed the way the Victorians viewed commodities. "Until the exhibition, the commodity had not for a moment occupied centre stage in English public life; during and after the exhibition, the commodity became and remained the centre of the turning earth..." 58 This aspect of 'centre' stage is important to keep in mind, particularly when considering the production and consumption of commodities before the Victorian era. Commodities were always produced and consumed in England, but what The Great Exhibition did, was essentially change the way the Victorians presented these commodities and how they were used to manipulate the public consumption sphere. Commodities during this time transcended their simple use and exchange values and instead became observably fetishised. I will go into more depth on fetishism when I discuss Zola's novel and drivers of female consumption in Chapter 3.

Not too long after the success of the Great Exhibition, modern style department stores

\footnotetext{
${ }^{57}$ Rappaport, Shopping for Pleasure, 119.

${ }^{58}$ Richards, The Commodity Culture of Victorian England, 18.
} 
around England began opening up. "During the 1860s and 1870s, the idea of the department store and a mass consuming public began to take shape in the streets of suburban London." 60 Department stores quickly gained more popularity due to their ability, "to exploit a vast array of goods, the large stores educated people to want things, and they played a crucial role in determining the essentials of middle-class life and aspirations. The stores themselves served as showcases as they became part of a new urban, public culture." ${ }^{61}$ Some shop keepers and aspiring entrepreneurs such as Whiteley gained success due to the rise of the popularity of department stores, but there were many others who were displeased and often economically hurt by this social development. "For many small shopkeepers from the 1880 s onwards...the department store became the most powerful symbol of all that they hated, they were the forces or organized capital that were crushing independent small enterprise..."62

Re-applying Marx's initial understanding of sensual capitalism, the Great Exhibition reflected a society which was progressive and developing. This is because the five human principals were activated and beginning to be fulfilled by capitalism. But, this was not the case for the entirety of the population. Many in the lower classes who were affected by cyclical depression, were struggling to attain basic human needs, let alone engage in pleasure consumption. Further, later as with the case of department stores and The Ladies Paradise, the senses become manipulated and controlled by capitalism, through controlled and planned sensual experiences.

\footnotetext{
${ }^{59}$ It is important to note here that department stores did not open up across England spontaneously, this change was more gradual than it first seems. Lise Sanders, Consuming Fantasies: Labor, Leisure, and the London Shopgirl, 1880-1920 (Ohio State University Press, 2006), 59.

${ }^{60}$ Rappaport, Shopping for Pleasure, 29.

${ }^{61}$ Gurney, The Making of Consumer Culture in Modern Britain, 21.

${ }^{62}$ Geoffrey Crossick and Serge Jaumain, Cathedrals of Consumption: European Department Stores, 1850-1939 (Routledge, 2019). In France, Germany, the Netherlands and Belgium, independent shopkeepers sought from the state measure to control this new competition, demanding for example that taxation should be proportional to their turnover or to the number of specialist departments...It was rare for such demands to elicit more than token responses...Governments were too attached to commercial expansion and the interests of middle-class consumers to interfere with the growth of department stores. Crossick, Cathedrals of Consumption.
} 
Returning to my discussion on the Great Depression, the Great Exhibition essentially foreshadowed one of the causes of the Great Depression. Whilst England was praising its economic and manufacturing prowess, it did little to console its increased production through publicised consumption. Instead, consumption is never addressed or considered throughout this event. Criticisms about not being able to purchase the commodities which were advertised in the Great Exhibition, only came much later after the event took place, and only from a small number of middle and upper class consumers. ${ }^{63}$ This emphasises the lack of importance politicians, economists and producers alike gave to consumption.

To conclude this section, while the Great Exhibition had its positive and negative impacts, which served in establishing the event as being one of historical and political economic importance, it offered a form of capitalist surplus which was engineered for the middle and upper classes alone. This is significant when considering the conservative arguments which arose during this time and reached a fever pitch in the 1880s. Moralists argued that this form of capitalist consumption was improper and in poor taste for the middle and upper classes. We can see from here, the beginnings to the antagonist relationship between capitalism and middle class (read: respectable) consumption. Secondly, the Exhibition fundamentally changed the way the Victorians viewed and consumed commodities. It taught the late Victorians how to engage in sensual consumption by “...teaching them to enjoy looking at objects." ${ }^{64}$ In his consideration of consumerism, Walter Benjamin wrote that, exhibitions "built up" commodities, "glorifying" their exchange value by which the commodities were fetishized. ${ }^{65}$ This is certainly the case when I discuss conspicuous and sensual consumption in more detail in my later chapters.

\footnotetext{
${ }^{63}$ Gurney, The Making of Consumer Culture in Modern Britain.

${ }^{64}$ Richards, The Commodity Culture of Victorian England.

${ }^{65}$ Rappaport, Shopping for Pleasure, 28.
} 
Thirdly, the Crystal Palace, was the start of the largest fetishisation of commodities ever witnessed in England. After this historic event, the Victorians mass produced numerous consumption guides and consumption was a frequent topic of discussion in upper class journals, magazines and conversations. This is important because it is a strong indicator that many people were engaged in a soft political discussion on consumption without truly being aware of it. They were politicized despite the obvious social and moral constraints against this.

Lastly, the Great Exhibition is also important in showing how consumption that was once regarded as a highly private matter, was pushed into the public sphere. Consumption no longer occurred behind closed doors or in the privacy of small shops. It was now out in the open, behind glass plated doors and windows, for all to see.

Post-1851 these trends would only increase. Goods which once possessed high exchange values and could only be attained by people of higher class, became more easily accessible even for some of the lower classes through mass production, thereby increasing their consumerism and making basic necessities out of what was previously considered to be luxury goods. To take this further, the late Victorians produced numerous guides and magazines which taught the Victorians about etiquettes and how to consume commodities properly. This meant that the Victorians suddenly found themselves having to consume more commodities than ever before just for the purpose of following social etiquette. Examples for this can be found in the many newspaper and magazine articles on various clothing attires for each social occasion. In this case The Ladies Paradise was no different, as it covered many of these aspects of Victorian middle class women's consumption. 


\section{Public space for women}

As department stores popped up around England, the "notions of gender, power, and the public sphere" ${ }^{66}$ of Victorian England, were challenged. This was largely due to the fact that the department stores offered "women a place in the public life of the city" 67 , in ways which were previously not possible. Generally speaking, public space was conceived as for males dealing with "public" issues like economy, politics and war. The presence of middle class women in the public sphere at department stores challenged this assumption, revealing how the "...consuming public [was] primarily if not wholly, a feminine entity." did this really mean for these women at the time?

The shopping experience allowed more middle class women to engage with their senses through smell, touch, and taste. On the topic of freedom, shopping meant “... a day 'in Town,' consuming space and time outside of the private home..."69 Zola was not alone in committing this new phenomena to literature. Such an example can be found in Charlotte Brontë's novel Villette (1853), where she describes the character of Lucy Snowe, a young woman who recently arrived to London. Upon looking “"out of her hotel window on her first morning in London she thought, “... I might venture out alone.” As Lucy stepped forth into the city's streets, her heart filled with "elation and pleasure." For this young single woman the idea of "walking alone in London seemed of itself an adventure.",70 Although Zola's novel, The Ladies Paradise was published a few years after Villette, there are some similarities where middle class women's freedoms are concerned. In one passage of the novel, Zola discusses the ways in which the wives "....were wandering freely through the

\footnotetext{
${ }^{66}$ Rappaport, 9.

${ }^{67}$ Rappaport, 9.

${ }^{68}$ Rappaport, 18.

${ }^{69}$ Rappaport, 5.

${ }^{70}$ Rappaport, 3.
} 
department..." ${ }^{71}$ Writers certainly capitalized on this idea that department stores granted women a new sense of freedom and purpose which they previously did not have.

Previously, moral and social obligations as well as pressures would have stopped Victorian middle class women from venturing into the public sphere, “...because when she stepped into the city streets, she threatened her own reputation and her family's social position." ${ }^{\prime 72}$ Such high regards for social morality and reputation carried on well throughout the nineteenth century and into the early twentieth century, and inhibited these women from achieving a complete and total sense of freedom in the public sphere. There were many social and moral risks which were associated with women who frequented the streets and cities. Bethany Hetrick argues, "historically, the notion of feminine "publicness" has metonymized the condition of the prostitute...in dramatic contrast to the bourgeois wife and mother, ruler of domestic and private space and nucleus of the family structure. This movement from private to public, then, implies a kind of prostitutionalization..." ${ }^{" 73}$ When it comes to middle class women's reputation and social morality there is no better person to discuss than Lynn Linton. In Chapter 2, I will fully analyse Linton's writings and develop a stronger understanding of the moralist arguments against women and sensual consumption.

Despite the moralist push back against middle class women attending the public sphere, not everyone in late Victorian was against their presence. The Victorian female shopper found support in, and excited those who could profit from, control, or at the very least direct her movements. ${ }^{74}$ These people were more often than not entrepreneurs, department store owners and authors. In other words, anyone who relied on women's consumption to earn their wages and increase their profits. These groups of people were often

\footnotetext{
${ }^{71}$ Émile Zola, The Ladies' Paradise, Oxford World's Classics (Oxford ; New York: Oxford University Press, 2008), 246.

${ }^{72}$ Rappaport, Shopping for Pleasure, 23.

73 'Equinoxes - A Graduate Journal of French and Francophone Studies - Issue 3', accessed 22 December 2019, https://www.brown.edu/Research/Equinoxes/journal/Issue\%207/eqx7_hetrick.htm.

${ }^{74}$ Rappaport, Shopping for Pleasure, 23.
} 
quick to defend and legitimize the migrations of the modern woman, in an attempt to shift social and economic thinking in their favour. This proves one particular aspect regarding the consuming woman and supports my earlier claim that the department store shoppers primarily consisted of middle and upper class women. Most considered that, "the West End shopper was invariably envisioned as a wealthy woman..."75 This means that the shopping women that were desired by businesses owners, and morally ostracised for being in the public sphere by moralists, had to have been at the very least of middle class. This supports my entire argument, regarding the late Victorians being cautious about middle and upper class women's sensual and public consumption. The reasons for this however, I will address later in my paper as my points develop.

Due to the power and importance of the middle class shopping women, it was unavoidable that shop owners and trade journals alike, eventually had to accept the female shopper as a crucial centre piece of capitalist system. Essentially, the modern woman not only represented moral degradation, but also a necessary shift in approaches to commercial and political economy. She was a necessary evil. With the rise of department stores, many women did indeed find occupation in shopping. Aside from the mistress of the house conducting her daily household duties by consuming goods for herself and her household. There were also women such as the shop girls, who found a new space for themselves in employment positions in department stores.

In this chapter I have provided the historical background leading up to the period of my focus - 1880-1890 Victorian England. By historicizing the events leading up to the publication of The Ladies Paradise, it is possible to determine the economic, social and political climate in England at the time. During the mid-Victorian era, England experienced

\footnotetext{
${ }^{75}$ Rappaport, 4.
} 
the cyclical and Great Depression, this is significant in that the cause of these depressions was ultimately the political economy in England at the time. By reducing middle class women to the private sphere and ostracising their engagement in public sensual consumption, England essentially propelled its economic problems of over production and under consumption. Middle class women who as I will show later, were the primary drivers of consumption and could have aided in the stabilisation of the English economy. But seeing as women engaging in any form of political economy was improper and went against all social morals, solutions for the English economy were sought outside of England. This hesitancy towards women's sensual consumption and their engagement in political economy is what this paper aims to address, beginning with The Ladies Paradise which exhibited signs of both sensual consumption and political economy. 


\section{Chapter 1: Zola and Zola's Novel}

In this chapter I will argue that Zola was a popular and successful author who sparked moral controversy due to the naturalist and political economic tone of his writings. To begin I will establish Zola's popularity and readership. Following this, I will determine the reception of The Ladies Paradise in England, to demonstrate the extent to which Zola sparked controversy as well as the reasons why he was considered a dangerous and an immoral writer. This chapter will also help build my arguments for Chapter 2 in which I analyse the conservative push against Zola and sensual capitalism.

Émile Zola was born in Paris on 2 April 1840 to a French mother and an Italian father. At the time of Zola's birth, his father was "a civil engineer, who was trying to secure government approval for the construction of a canal to bring a water supply to Aix-enProvence." 76 Zola's father passed away when Zola was six years of age, leaving Zola and his mother "in a precarious financial situation. In 1858 she moved her son to Paris, hoping to gain the support of her husband's friends; but this came to nothing and, for a few months in 1860, Zola lived in desperate poverty." 77 His earlier life struggles and experience with poverty set him apart from other writers of the time and possibly added to his popularity.

It is vital to note that Zola adopted a very liberal stance and demonstrated very progressive thinking on literature and the world around him from young adulthood, as can be observed by his reaction to the publication of Flaubert's novel Madame Bovary in 1856, when Zola was 16 years old. Whilst many criticised the novel for its impropriety, one of his biographers writes:

"Zola, did not laugh or jeer at Madame Bovary; he felt that a literary evolution might be at hand... The struggle which was to last all his life, one between his reason and his imagination, was beginning, if indeed it had not begun previously; for the

\footnotetext{
${ }^{76}$ Zola, The Ladies' Paradise, vii.

77 Zola, vii.
} 
oscillation which one observes in his writings between romanticism and realism—or naturalism as the latter became in its advanced stage — would indeed seem to be only a continuation of what had happened in his school days, when, in spite of proficiency in literary subjects, he had elected to follow a scientific course of study, in the midst of which, however, his literary bent had still and ever asserted itself." 78

This was a central turning point in the framing of Zola's mind and was essentially the beginning of his exploration of realist ideas in literature. Zola's reaction to Madame Bovary, illustrated how forward thinking Zola was by not siding with the popular critiques against the novel. Further, by pursuing science over other popular subjects at the time, Zola established his fundamental understanding of science which would later become a base for his realist literary ideas. This period was crucial to Zola, as it is the time during which Zola started showing signs of inclination to realism, and essentially created and developed his realist trademark which would be associated with him throughout his entire career.

In 1862, Zola took a job with the publisher Hachette, rising quickly to the position of advertising manager. During this time Zola wrote articles on various contemporary topics for periodicals in order to further supplement his income. ${ }^{79}$ Considering that Zola's novels often enclosed experiences from his personal life, it is possible to argue that Zola's appreciation of consumption and his accurate and concurrent depiction of consumption within The Ladies Paradise, was driven by his experiences in advertising as well as through observation of workplaces. Through his training in advertisement it is very likely that Zola witnessed the inner working of consumption and its importance in political economy, thereby resulting in Zola's appreciation of the consumption side of the economy.

In 1865 Zola published his first novel, La Confession de Claude, shortly after which he ended his employment with Hachette and went on to pursue writing as a full-time career.

\footnotetext{
${ }^{78}$ Ernest Alfred Vizetelly, Émile Zola, Novelist and Reformer: An Account of His Life \& Work, 2018, 73.

${ }^{79}$ Vizetelly, 56.
} 
Much of his success in writing is accredited to the success of La Confession de Claude, which "received unusual attention for the product of a comparative newcomer to fiction..."

Initially when Zola published his first ever work, the Contes à Ninon (1864), which was a collection of short stories, critics were quick to label Zola's realist ideas as a “"charming fault". ${ }^{81}$ It is no surprise that critics were quite rattled when La Confession de Claude was published, which embodied an even deeper realist undertone. Critics such as, “The waspish Vaperau, in his Année Littéraire, accused Zola of complacently mixing filth and shamefulness... Other critics, while deploring the novel's pessimism agreed that the young man was getting something off his chest, and that now this catharsis was accomplished, the public could look forward to better things." 82 Many of these critics agreed that their "main objection was the subject." 83 This would become a reoccurring critical appraisal throughout Zola's career, including the reception of The Ladies Paradise.

The reason why this case regarding La Confession de Claude, is so important is because it shows just how much criticism Zola generated from the start of his career. From the very beginning people were aware of and were discussing Zola, in a way that increased his popularity exponentially. No doubt, some new readers picked up his novels out of sheer curiosity about the man who generated so much talk. The reason for his popularity would be his politically charged and realist plots and characters which were considered risqué by English and French society at the time. This of course meant that there were many critics who gave very unfavourable reviews for Zola's novels, which undoubtedly generated even more interest, thereby benefitting Zola in the long term.

\footnotetext{
${ }^{80}$ John C. Lapp, 'The Critical Reception of Zola's Confession de Claude', Modern Language Notes 68, no. 7 (1953): 458, https://doi.org/10.2307/3043654.

${ }^{81}$ Lapp, 458.

${ }^{82}$ Lapp, 459.

${ }^{83}$ Lapp, 458.
} 
Despite many unfavourable reviews, there were equally many reviewers who applauded him for his progressive thinking, calling him, "“an author with a future," and one of the few novelists of the time who was also a thinker. ${ }^{84}$ One thing is certain: realism quickly became an associated and controversial trademark of Zola's, which helped him gain widespread popularity. By 1866, Zola's importance and influence in the literary world was solidified further, when he became the main champion of the Impressionist movement, which concerned itself with details and descriptions are used to convey sensory impression. ${ }^{85} \mathrm{~A}$ few years following that, Zola was appointed a Knight of the Legion of Honour and as a prominent figure in the French Academy, this was ultimate proof that despite all the negative reviews Zola was recognised as a permanent and important figure of French literature at the time. ${ }^{86}$ This recognition of Zola as an important figure in the French Academy shows that despite the negative critiques against Zola during the $19^{\text {th }}$ century, he was still recognized by many as an important figure at the time.

A few years prior to Zola's death, many newspapers claimed that he was "perhaps the most successful of living authors... whose income from literary work during the past five or six years has averaged $£ 12,000$ a year. The Gaulois paid him $£ 1,200$ to print 'Pot Bouille' as a feuilleton." 87

This statistic shows that despite the unpopular reviews he received, or comments from critiques claiming that Zola was unpopular, it is undeniable that he had to have been an in demand author in order to earn that high of an income for his novels. This means that he

\footnotetext{
${ }^{84}$ Lapp, 458.

85 Émile Zola, The Ladies' Paradise, Oxford World's Classics (Oxford ; New York: Oxford University Press, 2008), vii.

86 'The War In Zululand', Reynold's Newspaper, 29 July 1888, 5,

https://www.britishnewspaperarchive.co.uk/viewer/bl/0000101/18880729/041/0005.

87 'The Rewards Of Literature', Exeter and Plymouth Gazetter, 29 December 1887,

https://www.britishnewspaperarchive.co.uk/viewer/BL/0000508/18871229/089/0008?browse=False.
} 
influenced many readers with his ideas on realism and political economy, and very likely made many people discuss politics as a result.

Having said all this, it is still difficult to pinpoint the exact readership and reception of The Ladies Paradise, in part because it was assumed to be generally popular. Published in both French and English in 1883, The Ladies Paradise is the eleventh novel in the RougonMacquart series and is a sequel to the novel, Pot-Bouille. Pot-Bouille is the tenth novel in the Rougon-Macquart series and recounts the lives and activities of a group of residents who live in a block of flats in the Rue de Choiseul. One of these fictional residents was Octave Mouret, who is the owner of the department store known as The Ladies Paradise. The Rougon-Macquart series is a collection of twenty novels which follow the lives of two fictional families during 1852-1870 France.

The novel The Ladies Paradise revolves around the character of Denise Baudu, who after the death of her parents travelled from Valognes, to Paris with her brothers, in hopes of finding employment in the city. Early in the novel Denise secures a position at the popular department store "The Ladies Paradise", which is where she meets the owner Octave Mouret. The novel progresses with Zola looking at the inner workings of the department store through the perspective of the workers, and engages in themes of workplace conditions, gender inequality, morality, consumption and many more. The novel addresses many conflicts which arise from employee competition, career advancements and romantic relationships. In PotBouille, Octave Mouret is introduced as a seducer of women, whose aim was to overwhelm and manipulate women's consumption habits, a characteristic of his character which passed over to The Ladies Paradise. The novel ends with Mouret and Denise admitting their growing feelings for each other, and their marriage. 
In The Ladies Paradise, "Zola's desire is to broaden his social perspective and embrace the whole of socio-economic reality through his representation of the world of the department store." 88 The model for The Ladies Paradise was the Bon Marché, which was Paris's first and largest department store before 1914. In writing The Ladies Paradise, Zola studied the architecture and consulted various employees of the Bon Marché before writing his novel ${ }^{89}$ I bring up the Bon Marché here because it is exactly this department store along with the Great Exhibition at the Crystal Palace that influenced the English department stores which came after. ${ }^{90}$ Following from the ways of the Bon Marché, all commodities in late $19^{\text {th }}$ century department stores came with a price tag, an innovation previously absent from the Great Exhibition. Further, similarly to the Crystal Palace, the Bon Marché also "had large glass windows which showcased spectacular window displays in order to, 'attract shoppers into dazzling architectural surroundings and tantalized them with an atmosphere of abundance..." $" 91$ English readers of The Ladies Paradise recognized in this novel similarity in practices between the French and English department stores. One English newspaper article in 1888 noted on this similarity by stating that there is no better comparative establishment to Mouret's Ladies Paradise, than "the great Oriental house of Liberty and Co., in Regent-street." 92 This was a store which was very much alike to the one described in The Ladies Paradise. It had "remarkable prices" which could compete with any other establishment in the area and had spectacular window displays, with dazzling arrays of colours, silks, patterns and motifs. ${ }^{93}$ In order words, very similar to The Ladies Paradise and an embodiment of sensual surplus capitalism at its most-developed for the period.

\footnotetext{
${ }^{88}$ Zola, The Ladies' Paradise, 2008, viii.

89 Zola, ix.

90 Sanders, Consuming Fantasies, 60.

${ }^{91}$ Sanders, 60.

92 'A Ladies' Paradise', Bucks Herald, 5 May 1888, https://www.britishnewspaperarchive.co.uk/viewer/bl/0000270/18880505/003/0002. 93 'A Ladies' Paradise'.
} 
When talking about commodities sold at nineteenth century department stores, one might ask themselves, what is the class character of these commodities and who is the audience and consumer? It is a known fact that many items during the Victorian era such as expensive silks, cutlery and so on could only be purchased by the middle and upper class, thereby granting these luxury type commodities a middle and upper class status. In the case of The Ladies Paradise the commodities do not possess such strong class characteristics. On the one hand, The Ladies Paradise offers a public space in which consumers of all class levels can engage in sensual consumption. As stated by Gurney, when exposed to such consuming spaces, the classes become interlinked through their consumption. ${ }^{94}$ On a similar but different note, in Zola's novel the department store is not an isolated venture which existed solely for middle and upper class consumers. The character Mouret makes a conscious effort of including discounted and old season items at the front of the store in order to entice consumers of lower status and wealth. ${ }^{95}$ In this way consumers of all class levels engaged in ubiquitous consumption and the class character of the commodities was overlooked or became blurred. In some ways, this constant questioning of a commodity's class status is what drove innovation in fashion - to always be creating something new as couture and then have it quickly become available to the masses either via purchase or through real or imagined sensual relationship. The instability of a commodity's class character was a driving factor in consumer desire.

On the topic of capitalism, as Brian Nelson Professor of French and Head of the Department of Romance Languages at Monash University, Melbourne and translator of The Ladies Paradise, states in his introduction of his translated version of novel;

"The department store in The Ladies Paradise is a symbol of capitalism, the Second Empire, the experience of the city, and the bourgeois family; it is emblematic

\footnotetext{
${ }^{94}$ Gurney, The Making of Consumer Culture in Modern Britain.

${ }^{95}$ Zola, The Ladies' Paradise.
} 
of commodity culture and new systems of fashion; and it is the site of nineteenthcentury sexual attitudes and class relations." $" 96$

Through studying Zola's novels, with a particularly focus on Pot-Bouille and The Ladies Paradise, Nelson provides a very applicable and useful understanding of Zola's capitalism, and Zola's intentions with The Ladies Paradise. It is a novel that anticipated many trends to come and depicts consumption patterns which are still relevant to this day, as well as alluding to the deeper social and moral discussion which was taking place at the time regarding consumption and the senses.

What did late-Victorians at the time think of Zola, and in particularly his novel The Ladies Paradise? Sources such as: the Illustrated London News, Times of India, Globe, Lisburn Standard, Sporting Gazette and many more ran advertisements throughout the 18801890s for The Ladies Paradise. Some even described it as a "popular novel"97 or a "great story" ${ }^{\prime 98}$. The sheer number of these advertisements alludes to the scope of coverage and popularity that Zola's novels received. This may be in part due to the wider accessibility of Zola's novel due to increased translation and publication of them in England. But likely even more so, it was due to the discussions and controversies which were surrounding Zola throughout this particular time period, such as the Vizetelly lawsuit in 1888.

It is no secret or surprise that throughout Zola's career, "the sale of some of his books had been forbidden in England, Germany, and America..."99 due to the realist (read: gritty) tone of his novels. The Vizetelly case is an example of how the sale of three of Zola's novels were restricted in England. ${ }^{100}$ During the case, as covered the Birmingham Daily Post in

\footnotetext{
96 Zola, The Ladies' Paradise, 2008, x.

97 'Popular New Novels At Every Library', Illustrated London News, 13 October 1883, https://www.britishnewspaperarchive.co.uk/viewer/bl/0001578/18831013/053/0015.

98 'The Ladies' Paradise English Version Of The Great Story By Émile Zola', Globe, 11 January 1883, https://www.britishnewspaperarchive.co.uk/viewer/bl/0001652/18830111/083/0008.

99 'The Shop Girls Of Paris', Newcastle Daily Chronicle, 9 September 1892, https://www.britishnewspaperarchive.co.uk/viewer/BL/0001634/18920909/043/0004?browse=False. ${ }^{100}$ The three novels were; Pot-Bouille, Nana and La Terre.
} 
1888, “ publisher Mr. Henry Vizetelly...surrendered to his bail to answer an indictment charging him with exposing indecent literature for sale..."101 Moral and legal debates regarding what constituted as indecent literature at the time constituted majority of the proceedings. The Solicitor-General (Sir Edward Clarke), stated that, "There was not a female character mentioned whose reputation was that of a pure and decent woman...It was a prosecution for the publication of works which were filth and nothing else from beginning to end. He contended that the publication and sale of these books was to obtain money, and money alone, by pandering to the lowest taste of the most depraved of mankind..." 102 Vizetelly pleaded guilty and was ordered to "pay a fine of $£ 100$, and enter into your own recognisances in $£ 200$ to be of good behaviours and keep the peace for twelve months."103 This case is fundamental for two reasons. Firstly, it shows just how prominent the morality debate was at the time. The problem in this case was not necessarily the translation of these novels, or the volume of readership it received, but rather it was that these indecent novels were sold. Somehow, the sale of indecent literature was deemed to be beyond what was morally acceptable for Victorians at the time. Discourse about immoral production and consumption invigorated Victorian society. If this was not the case, then the lawsuit would have been framed very differently. The case would focus on the scope of indecency in Zola's novel and the translation of the work, rather than its sale.

Secondly, this case supports my point that Zola's novels were in demand during the Victorian era in general, including The Ladies Paradise. Although, the lawsuit was not related to The Ladies Paradise directly, it still had a connection to its prequel Pot-Bouille. Further, the case took place in 1888 , which is just five years after the publication of The

\footnotetext{
101 'Zola's Works In English', Birmingham Daily Post, 1 November 1888, https://www.britishnewspaperarchive.co.uk/viewer/BL/0000033/18881101/012/0005?browse=False. 102 'Zola's Works In English'.

103 'Zola's Works In English'.
} 
Ladies Paradise. When taking into consideration the scope of the charge of "£300", it is clear that this was a very hefty penalty, and that the Vizetelly case was not incidental. ${ }^{104}$ In order for Vizetelly to be fined this high of an amount for the sale and distribution of three novels, it is evident that Vizetelly must have been earning an income from his sales which was at least semi-proportional to the penalty he was charged. There must have been a very high demand for the novels he translated and was distributing, which establishes an impression of the scope of Zola's readership at the time. Considering that The Ladies Paradise was published in England during this time period, it is safe to assume that it was also in demand. While I cannot concretely prove how popular Zola was, it is possible to conclude that Zola's novels had to have been highly demanded.

The one aspect of Zola's popularity which I have not covered yet is, who was reading Zola? In order to determine this, I will conduct a brief cost analysis, of Zola's novels at the time. As stated in the 1886 Sheffield Daily Telegraph, which advertised the sale of Zola's novel, a copy of the novel with page engravings cost 6 shillings at the time. ${ }^{105}$ Other papers advertise that a cloth bound copy of the novel could cost readers 3 shilling 6 dimes. ${ }^{106}$ There was one final advertisement for The Ladies Paradise in newspapers such as the Globe, which advertised weekly segments from the novel, for the price of 1 penny. ${ }^{107}$ When looking at these prices we need to consider that the average unskilled worker earned around15 shillings a week, and a mid-low tier worker such as a stone mason earned an average of 29 shillings. When you combine these incomes with the cost of living, which saw rents and basic needs totalling to an average of 10-20 shillings a week, it is possible to deduce that it was the lower

\footnotetext{
${ }^{104}$ Equivalent to around $£ 8217$ in today’s inflation rate.

105 'New Volume Zola's Realistic Novels', Sheffield Daily Telegraph, 28 September 1886, https://www.britishnewspaperarchive.co.uk/viewer/bl/0000250/18860928/183/0004. 106 'M. Zola's New Book', The Queen, 5 March 1898, https://www.britishnewspaperarchive.co.uk/viewer/bl/0002627/18980305/139/0019. 107 ‘Advertisement The Ladies’ Paradise English Version', Globe, 11 January 1883, https://www.britishnewspaperarchive.co.uk/viewer/bl/0001652/18830111/083/0008.
} 
class and lower middle classes who constituted a large readership of the weekly penny journals (if they were literate, had the time to read and wanted consume literature that is). Despite this, there is little evidence that they were in fact purchasing the weekly penny journals and that they were consuming Zola specifically. Either way, it is important to note that it was not entirely impossible for the lower classes to be unaware about Zola's novels. On the flip side, we have the more expensive cloth bound and engraved copies of Zola's novels. Due to their cost, it is very unlikely that the lower class were purchasing these copies, and instead these were probably consumed by the middle and upper classes. It is possible to deduce that a large segment of Zola's readership had to have come from the middle and upper classes, because of the differences in life style when compared to the lower classes. ${ }^{108}$ Further, there were only a few papers advertising the penny journals, whilst there were significantly more adverting the cloth bound and engraved copies of the novel. This hints at the readership of Zola at the time.

On the topic of readership, it is impossible to deduce with exact certainty how many women were reading Zola, but we know that all kinds of print material, from magazines to scientific treatises like Darwin's The Origin of Species, to sensation novels were popular among women. ${ }^{109}$ It is therefore possible to conclude, that women consumed of Zola's novels including The Ladies Paradise.

Now that I have established the popularity of Zola's novels and his readership, I will discuss the various critiques surrounding The Ladies Paradise during the 1880s. Despite the scandals and discussions surrounding Zola at the time, there is evidence that The Ladies Paradise, "was warmly received by middle-class periodicals when an English edition of the

\footnotetext{
${ }^{108}$ The middle and upper classes had more time outside of the daily duties to engage in leisure activities such as reading.

${ }^{109}$ Kate Flint, The Woman Reader, 1837-1914, (London: Clarendon, 1993).
} 
complete work first appeared." ${ }^{110}$ As more readers got their hands on the novel, critics were quick to point out the indecencies and immoralities conducted in the novel and a new moral debate ensued. Similarly to his earlier novel La Confession de Claude, and the novels following, The Ladies Paradise equally received polarising reviews and opinions, thereby generating more discussion and controversy on the novel.

Despite the scandals and discussion surrounding Zola at the time, there is evidence that The Ladies Paradise, "was warmly received by middle-class periodicals when an English edition of the complete work first appeared." ${ }^{111}$ As more readers got their hands on the novel, critics were quick to point out the indecencies and immoralities conducted in the novel and a new moral debate ensued. Similarly to his earlier novel La Confession de Claude, and the novels following, The Ladies Paradise equally received polarising reviews and opinions, thereby generating more discussion and controversy on the novel.

Before addressing what some of these opinions were, it is important to consider that critics writing for papers and journals at the time, did not only differ in their opinions due to differences in their personal tastes. The type of papers they were publishing their articles in largely impacted and at times encouraged the critics to adopt particular opinions. Some writers such as Lynn Linton, who will become a central character in my paper throughout chapter 2, published their articles in particularly conservative papers which at the upmost cared about preserving social morality and pushing against spontaneous, sensual capitalism. Hence why their opinions and reviews, as I will show in this chapter and throughout my thesis from here on, are so centred on morality. On the flipside, many of the critics who were supporting Zola and his writing, wrote for more liberal and artistic papers and hence shared a more progressive view and take on Zola. The fact that these two antagonistic sides existed

\footnotetext{
${ }^{110}$ Gurney, The Making of Consumer Culture in Modern Britain, 89.

${ }^{111}$ Gurney, 89.
} 
alongside each other, shows that the late Victorians were divided in matters concerning capitalism, progression, feminism and morality. Indirectly this alludes to the possible discussions about political economy that were taking place below the surface at the time. These conflicting opinions even enter the literary realm, which arguably for the late Victorians was a separate sphere from political economy. As I will prove later, a large reason for why these two sides existed was particularly due to the political economic discussions which were taking place in places such as The Ladies Paradise.

Going back to the reception of the novel in England, in 1886 English reviews derogating Zola flooded English newspapers, such as in the Norwood News. Many of them appeared to "agree that Émile Zola is a great corruptor"112 who has "...flooded French literature in the prostituted name of Art. His sole interest in some of his characters lies in the fact that they are human..."113 Their biggest objection, as mentioned earlier in this chapter, was the subject matter of Zola's writings and his realism. What we also see being demonstrated here is a form of "othering." 114 Zola was recognized as a threat to social order and morality with his realist politically charged novels, but because of his Frenchness. Linda Colley in her book, Britons: Forging the Nation, 1707-1837, argues that the British "othered" European countries such as France, in a move to stabilize and solidify British culture. ${ }^{115}$ In regards to France, England took this aspect of "othering" even farther because: 1) France was the closest neighbouring country to England, 2) the two countries held religious differences and, 3) France was England's enemy across centuries. In other words, the English throughout history including the late Victorian period, "othered" France and associated any cultural or economic differences between the two countries, to be a form of immorality or failure on

\footnotetext{
112 'Reviews', Norwood News, 17 April 1886, 5, https://www.britishnewspaperarchive.co.uk/viewer/bl/0002308/18860417/131/0005. 113 'The Gospel According To Robert Browning', Pall Mall Gazette, 5 June 1888, 1, https://www.britishnewspaperarchive.co.uk/viewer/BL/0000098/18880605/002/0002?browse=true. ${ }^{114}$ Linda Colley, Britons: Forging the Nation, 1707-1837 (Yale University Press, 2005).

${ }^{115}$ Colley.
} 
France's behalf. Which is why when Zola, who was French, gained popularity in England, many conservatives were outraged and attempted to curb his popularity through harsh critiques and the reinstatement of good English morals.

Zola stirred up a big discussion in France regarding the legitimacy and subject matter of his novels, but, the distaste for Zola in France was nowhere near to the degree of that in England. This is largely due to the political climate in France at the time. The French already had the Bon Marche, and were more open to embracing unbridled capitalism, especially in the realm of middling-to-upper-class consumption and sensualism. England in comparison, as I have pointed out thus far, was very cautious to embrace this facet of capitalism and ultimately kept falling back on "morality" as a way of legitimising their stance against undisciplined sensual capitalism. It was only when Zola's novels became largely popular and in demand in England that the English middle class acknowledged Zola as a problem in England.

Another significant aspect of the quote from above regarding French literature is the discussion around art. The word "prostituted" was used here to argue that realists such as Zola earned money off of ruining art by exploiting it through sexuality. Where the French allowed some of Zola's antics to pass under the guise of art, in the eyes of the English middle class, Zola was by no means an artist, he was simply a crass capitalist. For them, Zola essentially was earning money through the publication of immoral and sexual novels which were polluting the minds of its readers. This is why on the surface level, Zola was considered a threat to English social morality. But, this I argue is simply the surface level argument for why some people in England were so against Zola's novels. On a deeper level, Zola was a threat because he was very popular amongst female readers, the leading consumers of novels at the time. With his works being very politically charged, middle class women who read Zola, were exposed to politics that, critics argued, were socially unacceptable or 
unrespectable. By reading novels such as The Ladies Paradise, middle class women were more likely to engage in political discussions, by merely discussing the contents of the novel. This was ultimately what the Victorians were most afraid of, when it came down to Zola and capitalism. I will expand on this argument as my thesis develops. Going back to critiques of Zola, in another English newspaper, a critic argued that:

"The greatness and decline of Émile Zola is the one subject of conversation for the time being. His novel now in course of publication in daily feuilletons, in the most immoral of Paris papers, is so excessively filthy that many of this most constant readers have given it up in disgust, though one-fourth of the dirty work still remains to be published. It was necessary, therefore, that something should be done to re-vivify public curiosity, and Zola, who is a dab at puffing, has arranged with his friends and supporters a very ingenious plan for stimulating the relaxed attention of the lovers of prurient reading, for literature it cannot be called. Some half-dozen "naturalists," therefore, wrote a protestation to the Figaro the other day, against the nastiness of their master's latest production, and informing the world that they had ceased to be his disciples." $" 116$

There is a possibility that these type of reviews which argued against Zola's popularity did so in an attempt to curb the popularity and demand for his novels. By presenting Zola as an immoral writer who was also becoming increasing unpopular, English periodicals hoped they could dissuade readers from picking up his novels. This negative form of press I argue may have been a form of societal control in a bid to re-instate social morality by teaching readers the rights and wrongs of literary writers. Moreover, Zola's influence and success became so widely known that he was even imitated by aspiring writers. It was commented in the Edinburgh Evening News, “That so remarkable a writer as Émile Zola should find imitators in England was quite inevitable; the wonder is that they have been so long in arising." 117 The fear did not only lie in Zola's popularity and scope of his readership, but also in his effect on aspiring writers who were imitating him. The concern amongst the late Victorians was that

\footnotetext{
116 'Parisine', Manchester Evening News, 22 August 1887, 2, https://www.britishnewspaperarchive.co.uk/viewer/bl/0000272/18870822/004/0002. 117 ‘Occasional Notes', Edinburgh Evening News, 1 December 1884, 2, https://www.britishnewspaperarchive.co.uk/viewer/bl/0000452/18841201/003/0002.
} 
English writers were being infected by Zola, and were under risk of adopting styles of writing, political ideas and realist aesthetics similar to Zola's. Zola's scope of infection was spreading to England. This was a large concern for the late Victorians at the time, as it meant that Zola could no longer be "othered" and considered a French issue alone.

With Zola's newfound imitators there was a risk of other writers writing about and normalizing the publication and readership of immoral novels in England. I wish to bring attention to a 1887 Manchester Evening News article on Zola's writing, where Zola was criticised as forming an "...ingenious plan for stimulating the relaxed attention of the lovers of prurient reading." The words "ingenious plan" makes it seem as though Zola's novels are not natural or a form of "art" but rather are premeditated plots, conjured for the sole purpose of stimulating "lovers of prurient reading," or for the purpose of soiling social morality through sensual satisfaction. It is writing such as this that remind us that there was a push back from the conservatives at the time against sensual consumption. Briefly going back to my point regarding Zola's imitators, it is this soiled stimulation of moral minds that the late Victorians, in particular the conservatives, were most fearful of.

As Lynn Linton mentions in her essay Our Small Sins, one of the greatest sins that middle and upper class women committed was the "sin of sensationalism" particularly "sensationalism in literature". ${ }^{118}$ Sensation fiction or "sensationalism in fiction" is a branch of fiction which grew in popularity in England during the Victorian era, especially from the 1860s on ways. Novels in this genre typically had a few things in common: they contained shocking and controversial subject matter such as but not limited to, seduction, murder and adultery. ${ }^{119}$ By many accounts and moralist claims, Zola's novels including The Ladies

\footnotetext{
${ }^{118}$ Elizabeth Lynn Linton, Ourselves, Essays on Women (Chatto and Windus, 1884), 69, http://archive.org/details/ourselvesessays00lintgoog.

${ }^{119}$ Harold Bloom, ed., The Victorian Novel, Bloom's Period Studies (Philadelphia: Chelsea House, 2004$), 108$.
} 
Paradise were considered sensation fiction. Zola was caught up in this wave of sensation fiction and the audience and discussion it stirred, which is possibly why there was so much push back against his novels in England. With sensual literature becoming increasingly available on the market, middle class women had easy access to works which were sensually stimulating. In comparison to these works, literature which did not stimulate the senses became "dull reading". ${ }^{120}$ In essence, these women became stimulated by sensual literature in such a way that morally acceptable literature which did not engage with the senses, became dull in comparison. This is a strong indicator of how middle class women engaged in sensual capitalism and how they gradually desired to engage in more sensual consumption over time. This is exactly why sensual consumption is a branch of capitalism. By manipulating the sensual pleasures the consumer receives through bodily receptors it is possible to stimulate feelings of pleasure and desire, which can quickly become addicting over time. Considering that previously the earlier Victorians did not have as easy access to sensual pleasure in a capitalist sense, it is possible that their senses were heightened by the time department stores and sensational literature came about. By desiring to re-live the feelings of pleasure that sensual consumption grants, the Victorians were very likely to engage in further capitalist practices, there by legitimising capitalism and supporting the system, despite the moralist push backs.

The previous quote also highlights a re-occurring point when researching further into moralist arguments at the time. Writers condemned readers who fell into sensual traps laid out by authors such as Zola. It also raises the question, did consumption have to be moral in the nineteenth century, in order to be socially acceptable? Going back to Marx, consumption restricted by morality would severely infringe the capitalist system as consumption needed to be continuous. When the writers are condemning readers for engaging in sensationalism and

${ }^{120}$ Elizabeth Lynn Linton, Ourselves, Essays on Women, 69. 
immoral consumption, it is unclear as to what moral consumption means to them. Further, it is also unclear as to how many capitalist practices were considered immoral at the time. One thing is certain however, consumption was definitely regarded as an important branch of capitalism which the moralists tried to constrain. There are two points regarding why this is important to keep in mind. Firstly, it provides evidence that consumption is considered as an important branch of capitalism in action. Although theorists such as Marx and Bagehot failed to discuss consumption in a three-dimensional way, the moralists and writers such as Zola are doing their part on the matter. Secondly, it appears that consumption has to be morally acceptable in order for it to be respectable. But, as Marx shows in Capital, capitalism does not operate on respectability. Instead it requires a constant production and consumption of commodities, all the while disregarding morality and purpose, which is why I would argue that late Victorian England was not prepared to embrace the type of capitalism Zola was writing about. In order to do so, the Victorians would have to embrace consumption and sensual capitalism in all its stages, along with the consequences from it such as women's emancipation and a considerably more politically educated public.

Continuing my analysis on the critiques surrounding The Ladies Paradise throughout the $1880 \mathrm{~s}$, in another article a writer critiques middle class women for their lack of control in regards to consumption. The Ladies Paradise is described as an "... apotheosis of monster houses. It is a satire, severe if distinguished, upon woman's insatiable appetite and desire for dress." ${ }^{121}$ We learn two very important things from this. Firstly, The Ladies Paradise was described as monsterous houses because they: provided women of all classes with a place of work, produced senses and experiences, provided a place of consumption and supplied women with supplies required for maintaining their household economies. Further, Zola's

\footnotetext{
121 'Literature', Freeman's Journal, 7 December 1883, 2, https://www.britishnewspaperarchive.co.uk/viewer/BL/0000056/18831207/004/0002?browse=False.
} 
"monster houses" of production which are being described in the previous quote also mirror the monstrosity in consumption which is occuring simultaneously.

Without consumption, these production houses would cease to exist. This framing of production and consumption is a common flaw of political economy during this time preriod. Writers, politicians and economists alike were quick to disregard the importance of consumption and instead narrowed down on their understanding of production alone. As I have argued thus far, consumption played a large role in the capitalist economy at the time. A bigger production house is a strong indicator of how large consumption must have been, which supports my claims that the Victorians were most engaging in conumption and were indeed on a very general level, consuming more than before.

My second point refers to middle class women and their appetites for consumption. This article is an example of just one of the many articles which frame middle class women's consumption in a negative light and as an uncontrollable desire. But when considering the capitalist economy, middle class women played a central role in late Victorian England particulary through their consumption habits and domestic economies. Women were the primary consumers in Victorian societies due to the way household economies worked. As I showed in my historical background the shop owners were aware of this, which is why the specifically set out to lure middle and lower class women into their stores, thereby feminizing the public consumption sphere. I will go deeper in my discussion on the importance of womens consumption on the political economy, as well as the moral limitations and boundaries of this in Chapter 2.

Aside from the many varying writers who wrote articles for papers, there is one particular critic who comes up frequently in the Zola debates during this time period. This critic is none other than Lynn Linton. Although I will fully introduce Linton in my next 
chapter, I wish to draw on one of her critiques on Zola in this section. This is for the purpose of putting emphasis on the extent to which the negative critics wrote about Zola as well as what they were actually saying. Before moving on to Linton's article, I wish to point out that Linton wrote primarily for conservative papers and her opinions are akin to others in her field who were pushing against unbridled captalism. In one of her articles, similar to some of the ones previously discussed, Linton makes a point that Zola capitalizes on the senses in order to entice more readers:

"The truth is that M. Zola purged of "nastiness" would not find a hundred readers. He is dull even when he is at his nastiest, but he is supremly turgid when he tries to be harmless... It is difficult to get rid of the impression that $\mathrm{M}$. Zola makes his books indecent because he panders shamelessly to a depraved public taste in that direction. It would be so easy to make that nobel aim of his -the evolutionary transmission of sin to third and fourth generations intelligible and forcible without the abominable freedoms he takes with all the sanities and sanctities of life. Filth is not accidental but systematic in M. Zola's books." 122

Linton effectively states that Zola is popular only because his novels sensually impact readers. Over the course of my thesis I have given evidence to suggest that middle class women constitued a good portion of Zola's readership, so when Linton states that he is writing "to a depraved public" she is essentially saying that women who consume Zola are immoral and depraved creatures. This position on middle class women's consumption is unsurprisnig from Linton when we take into the fact that Linton was severly against the female sex in general. In her eyes women were weak, feable creatures who could never live up to the success of men. ${ }^{123}$ In her article for the Newcastle Daily Chronicle, Linton is essentially condemning the behavior of middle class women who engage in sensual

\footnotetext{
122 'A Woman's View Of Zola', Newcastle Daily Chronicle, 4 January 1889, 4, https://www.britishnewspaperarchive.co.uk/viewer/BL/0001634/18890104/035/0004?browse=False. ${ }^{123}$ Elizabeth Lynn Linton, The Girl of the Period : And Other Social Essays (London : Richard Bentley \& Son, 1883), http://archive.org/details/girlofperiodothe01lint.
} 
consumption through the consumption of Zola's novels. This further supports my claim that by reading Zola's novels, including The Ladies Paradise, middle class women were engaging in sensual capitalism.

One other point regarding Linton's statement concerns her comment regarding Zola systematically writing about "filth". Upon first glance it is not entirely clear what Linton means by "filth" as she does not supply the reader with a concrete definition or an explanation of her application of the word. Linton is being vague on purpose in her writing and assumes that the readers will come to their own conclusions about what "filth" she is writing about. After reading the history surrounding this time period, Linton's other works and the newspaper articles during this time period, my interpretation of the "filth" that Linton writes about concerns: sex, senses, consumption, breach of social morality and conduct, exposure to inappropriate topics, religion, gender and more, most of which appear throughout Zola's novels. In a sense "filth" refers to everything deemed inappropriate by Victorian standards at the time. An interpretation of this word that I offer in this paper considers "filth" as relating to the sensual capitalist practices that are taking place in The Ladies Paradise.

Here Linton represents a conservative stance against unbridled capitalism through arguments on social morality. The arrival of department stores increased middle class women's liberty and consumption across England. Zola's novel, only re-instates and observes social capitalist practices and female consumption behaviours. Writers of conservative backgrounds such as Linton, prove that England was not fully embracing capitalism. The reason being, to restrain women's liberty and rights in the public consumption sphere as well as their exposure to political economy. Granted I have not discussed so far how middle class women discussed consumpion or political economy, but this is a part of my argument that will be proven when I discuss household economies and the drivers of female consumption. 
I have alluded to only a few of the many critiques which were submited by reviewers to English newspapers. However, I wish to point out that not all reviews on The Ladies Paradise were negative. Unsurprisingly, Zola received a lot of praise for his work and his forward thinking. In one particular article a critic stated that, "Most people are ready to admit that Zola's purpose was always good..."124 On a similar note, another critic praised Zola for being a "...great defender of the humblest and poorest victims of our modern State capitalist organisation. He was an advocate of the good, healthy enjoyment of life by everyone... He hated with his whole powerful soul oppression in any form: political, religious or national...he shows the bestiality and degradation of the middle classes with their sensuality and lust for gold to which they sacrifice their honour, their wives and their daughters..." ${ }^{125} \mathrm{~A}$ recurring word in these articles was the use of "good" creating the impression that supporters of Zola's novels generally agreed that Zola was a man of good character. It was articles such a these that added positivity to Zola's reputation and helped fuel the opposing side to the controversies surrounding him.

Aside from critics and reviewers, Zola received overwhelming support for The Ladies Paradise from his female readership. In a new column called $A$ Woman's View of Zola, it was stated that "It is surprising...that among women should be found the critics and apologists who have studied the man and his works with an attention manifestly deeper than that of males..." ${ }^{126}$ This notion of middle class women studying Zola with deeper attention than their male counterparts and will form a large section of my discussion in the following chapter. This is largely because Zola acted as a bridge between the middle and lower female class, as well as production and consumption. Zola essentially connected these systems

\footnotetext{
124 'Mr. Stanley At Melchp', Newcastle Evening Chronicle, 15 July 1890, 4.

125 'Zola', Freedom, 1 November 1902, 2, https://www.britishnewspaperarchive.co.uk/viewer/BL/0003243/19021101/003/0002?browse=False. 126 'The Shop Girls Of Paris'.
} 
together, which gives us the opportunity to analyse it amidst the larger system of, sensual capitalism. On a different but equally important note, we also gain evidence from this article that women possibly constituted a larger proportion of Zola's readership than I earlier stated. Considering that there were no obvious papers which discussed male readership of Zola's novels at the time, it is only possible to conclude two things. Firstly, middle class women were almost certainly reading Zola more than men. Secondly, it is possible that middle class women's consumption of Zola's novels were in the papers so frequently because of the conservative agenda against middle class women's sensual consumption. This piece of evidence will prove useful when I enter the second segment of my argument regarding sensual consumption, women's emancipation and the exposure of women to political economy.

To conclude this chapter, I have shown that Zola established his trademark as a realist from the early stages in his life. Controversies surrounding his earlier novels helped him earn attention and publicity from the very beginning of his career as a writer and foreboded the future of his literary career. Despite the controversies and negative reviews, Zola was a widely known and successful writer, who's income supported his fame. The Ladies Paradise was accepted into English society in a very similar fashion to his previous novels: with controversy. I have also determined that Zola's readership and the readership of The Ladies Paradise for the most part consisted of middle and upper class women. Lastly, I have briefly shown some of the ways in which the Victorians were hesitant to accept unbridled sensual capitlism. This final part, will become even clearer in my following chapters where I discuss and analyse Linton's works and househould economies in more detail. 


\section{Chapter 2: Lynn Linton and Moralism}

In this chapter I will introduce Lynn Linton, as well as some of her most notable works. The purpose of this chapter will be to show the ways in which Linton critiqued Zola, particularly his novel The Ladies Paradise. Secondly, I will aim to establish Linton's contradictory character and her popularity as an anti-feminist writer in order to emphasise her importance to the moralist arguments against unbridled capitalism. Linton's writings in The Girl of The Period and Our Small Sins will be critical in determining the core of the moralist arguments and their impacts on the reception of Zola's novel and middle class women's consumption. Further, I will analyse the ways in by which Zola and Linton engage in political economic discussions, thereby supporting my claim that relevant political economic discussions were taking place in literature. To make my case, I will compare excerpts from The Girl of The Period, Our Small Sins and The Ladies Paradise. Lastly, I will address how Zola and Linton affected the women's rights movement through their writings and why increased women's rights were repressed in England at the time.

\section{Lynn Linton Biography}

Eliza Lynn Linton, is a writer who frequently comes up throughout the Victorian era, but more importantly for my paper, she is vital to my discussion of Zola, as she was one of his greatest critics. Linton was most well known for her anti-feminist writing and independence as a distinguished female writer and novelist in the Victorian era. Linton was privileged to be born into a family of comfortable means in 1822, Keswick, England. A privileged life style impacted Linton's view of the world, and her place in society from an early age, but her life was not without its struggles too.

In her autobiography, Linton presents her internal struggles, in particular her emotional pain and motherly deprivation. Psychohistorian and Linton biographer Nancy Anderson acknowledges in her reading of Linton's autobiography that Victorians 
“...typically exaggerated in their autobiographies the misery of their childhood in order to heighten the romantic pathos of theirs lives... Nevertheless, the circumstances of her family life, and the personality traits she developed, suggest that her portrayal of a painfully unhappy childhood, recounted histrionically and with excessive self-pity, is emotionally authentic."127 So it is safe to presume, that Linton had a relatively difficult childhood, despite being of a privileged background. This is mostly attributable to her familial connections after her mother passed away in birth. Being the twelfth child in the family and losing a mother from birth, Linton found herself without a mother figure to guide her through life. To make matters worse, Linton and her father, Vicar James Lynn, had a very turbulent relationship, with the latter more often than not neglecting his children and applying harsh discipline. ${ }^{128}$ This strict discipline was even harsher where Linton was concerned, leading her to feel anger and rejection from her father. In latter stages of her life Linton wrote about her father in her work often and critiqued him as being “...weak, insolent, and unambitious." ${ }^{29}$ This application of her personal life experiences in work was not only limited to articles about her father. The death of Linton's mother arguably played an even more crucial role in the development of Linton's character. As Anderson writes in her psychobiography of Linton, “...Eliza felt strong unconscious anger at her mother for abandoning her by dying, as evidenced by the unpleasant rejecting mothers who populate her novels. In her heated invectives against women's rights, in which she insisted again and again that a mother's place is by the cradle, she was in part expressing her own angry feelings of maternal deprivation." 130 This is an example of a way in which Linton applied her personal life experiences in her work and

\footnotetext{
${ }^{127}$ Nancy F. (Nancy Fix) Anderson, Woman against Women in Victorian England : A Life of Eliza Lynn Linton (Bloomington : Indiana University Press, 1987), 3, http://archive.org/details/womanagainstwome00ande. ${ }^{128}$ There is speculation that Vicar Lynn, was very close to his wife, and was deeply hurt by her death. Due to this, the Vicar blamed Linton, for causing her mother's death. Aside from her father, Linton also did not get along with her older siblings who often bullied and ridiculed Linton due to her looks, short-sightedness and intellect.

${ }^{129}$ Anderson, Woman against Women in Victorian England, 5.

${ }^{130}$ Anderson, 10.
} 
demonstrates how Linton's childhood impacted her personality and anti-feminist stance into adulthood.

To make matters worse where family was concerned, Linton experienced bitter jealousy for her sister Lucy, who represented everything Linton was not. Where Lucy was elegant and feminine, Linton was tomboyish, energetic and ambitious, all of which were characteristics which in the nineteenth century “...were considered masculine..."131 Linton tried to internalize this sexual conflict, but ultimately, her "male identification was so strong that she wrote her autobiography, signed with her own name, in the persona of a tall robust male, Christopher Kirkland." 132 She explained that she characterized herself as a man because she could not publish her own autobiography "“without some veil as this of changed sex and personation.'"...The sex reversal was, however, not a screen but a mirror, which reflected her deep unconscious feelings of maleness." ${ }^{\prime 133}$ This male identification and Linton's personality were a huge factor in her success in her patriarchal society. As the women's rights journal Victoria Magazine said in May 1879, quoting an unnamed famous woman, "exceptional women must be male souls confined within female bodies." ${ }^{134}$ Whilst Linton “...prided herself on her masculine attributes...she accepted the prevalent Victorian view of women as weak, irrational, and superficial...In Eliza's view, men are, as she entitled on of her articles, "Superior Being"...In a letter written near the end of her life, she admitted that "I hate women as a race. I think we are demons. Individually we are all right, but as a race we are monekyish, cruel, irresponsible, and superficial." ${ }^{135}$ It appears that a large portion of Linton's hatred for women stemmed from her personal feelings of shame and rejection.

\footnotetext{
131 Anderson, 11.

132 Anderson, 12.

133 Anderson, 11.

134 Anderson, 12.

135 Anderson, 12.
} 
Growing up Linton did not receive any formal education as her father did not concern himself with his children and was firmly against female education. In many ways this worked in Linton's favour as she had the freedom to self-teach and had access to a large variety of books from the home library without any pedagogical interference. This very likely may have been the period during which Linton developed some of her primary socialist views. By the time Linton entered young womanhood she was excited to leave the house and create a life for herself elsewhere. ${ }^{136}$ In 1845, against her father's wishes, Linton set off to London where she would earn her living as a writer. Her first novel called Azeth was published in 1847 and garnered only a small following. Shortly after her first novel, Linton joined the Morning Chronicle where she worked as a journalist until 1851. During the early stages of her career, particularly in the 1840 s to 1850 s, "Linton was an advocate of women's rights..."137 as can be witnessed in her novel Realities.

Drastic changes occurred in Linton's life in 1851, with the release of her third novel Realities, which received very poor reviews. In this novel, Linton introduces the protagonist Clara, who is a socialist and a freethinker, and who in many ways is similar to Linton in that she was self-educated and came to London to earn a living, choosing a life of freedom rather than marriage. Linton progresses the story by constructing shocking events (to readers at the time) and showcasing her radical views. Examples of this can be seen in her novel, when Linton "... attacked the double standard, and blamed prostitution on the low wages and harshness of laissez-faire political economy... She criticized the callousness of the Church, and suggested that if Christ were to come back, he would return as a communist."138 Linton broke all moral and respectability boundaries by engaging in such topics of discussion. It is

\footnotetext{
${ }^{136}$ Due to the competiveness of the marriage market at the time, as a result of a child-boom in the 1830 's, Linton would not fare well on the market. She was described as not being a handsome woman, and possessed very few of the ideal feminine traits of a Victorian woman, which is why marriage was not really an option for her at this time.

${ }^{137}$ Anderson, Woman against Women in Victorian England, 40.

${ }^{138}$ Anderson, 60.
} 
little wonder that many Victorian readers found this novel in poor taste. For example, one journal, The Anthenaeum, said that in her attack on "Pharisaical respectability," she "raved like a Pythoness.", 139

To make matters worse, precisely one month after the Realities was published, Linton was fired from the Morning Chronicle in April 1851. Linton writes in her autobiography that it is unclear why she was fired, "“All that I do know is, I suddenly failed to please...I was abruptly dismissed, and told to go to the devil, but never to show my face in that office again." ${ }^{140}$ As stated in an article by Clare Walker Gore entitled, "The Sensational Eliza Lynn Linton," although Linton's novel Realities was politically radical and overtly feminist, "after its hostile critical reception Linton adopted a conservative and even misogynistic voice in her journalism, forging a highly successful career out of bemoaning the supposed shortcomings of modern women in the periodical press." ${ }^{141}$ Linton was so deeply impacted by this event, that she did not publish, "another novel for fourteen years."142

From an early stage in her career Linton capitalised on her ability to shock readers and create controversy. This skill in many ways is comparable to Zola's ability to capitalise on the sensuality of his novels, and is just one of the ways in which Zola and Linton are similar. Linton's skill in creating controversial discussions will also play a major part in later in this chapter where I address the ways in which Linton ignited the women's rights movement with her anti-feminist articles and the ways in which she exposed her readers to discussions of political economy.

\footnotetext{
139 Anderson, 61.

${ }^{140}$ Anderson, 62.

${ }^{141}$ Clare Walker Gore, "The Sensational Eliza Lynn Linton," Women: A Cultural Review 27, no. 3 (2 July 2016): 329-31, https://doi.org/10.1080/09574042.2016.1256122.

${ }^{142}$ Anderson, Woman against Women in Victorian England, 63.
} 
When looking at Linton's life, it is clear that she was in a constant conflict with her inner thoughts and portrayed at times a very contradictory character. This can best be highlighted in her 1854 article titled, $A$ Vindication of the Rights of Woman, in which Linton praised eighteenth century philosopher and writer Mary Wollstonecraft for her work on women's rights. This particular article was described by reviewers at the time as being "'one of the boldest and bravest things ever published." ${ }^{143}$ Luckily for Linton, this essay was swept under the rug by reviewers when her first essay on antifeminism was published in the same year. Later in 1854, Linton published her first of many antifeminist works, in an article entitled Rights and Wrongs of Women for the Household Words journal on $1^{\text {st }}$ April, in which she set forth the anti-feminist arguments which later became her stock-in-trade. Refuting specifically the opinions of the American advocate of women's rights Thomas Wentworth Higginson, Linton argued that a woman "teaching, preaching, voting, judging, commanding a man-of-war and charging at the head of a battalion - would simply be an amorphous monster...The woman who is too gifted, too intelligent, to find scope for her mind and heart in domestic duties is simply not a woman. She is a natural blunder, a mere unfinished sketch." ${ }^{144}$ Although, Linton initially possessed a progressive and feminist mind-set, she had to adapt to market demands and create a niche for herself in a patriarchal society. When comparing this article with her earlier novel Realities, the juxtaposition is substantial and reflects Linton's “...chameleon-like ability to match the editorial tone of diverse journals."145 It also demonstrates the extent to which Linton was in conflict with her view on middle class women and their rights. A year later, Linton published another article for the Household Words, in which she solidified her trademark as an anti-feminist writer. "In this essay, entitled 'Passing Faces,' published on April 14, 1855, she caricatured women by comparing

\footnotetext{
143 Anderson, 71.

${ }^{144}$ Anderson, 71.

145 Anderson, 72.
} 
them to animals. She described the greyhound woman, the cat, the cow, the poodle, the rat, and so forth." ${ }^{146}$ For the following years until 1868, Linton primarily wrote articles such as previously mentioned to support her free life-style. Linton died in 1898, at which point she had published over 20 novels and numerous essays.

The purpose for focusing in so much detail on Linton's personal life is to establish her contradictory character in the hopes of creating a clear narrative of Linton's distaste for Zola and his novels later in this chapter. As I have already begun to mention, Linton was more than simply an anti-feminist. Not only did she write about political economy in ways comparable to Zola, but she essentially helped propel Zola's popularity and ignited the women's rights movement by creating premeditated controversy. One of said controversies can be found in The Girl of the Period.

\section{Lynn Linton Writings and Influence}

Linton's essay titled The Girl of the Period, was originally published in 1868, but later was re-published in 1883 by Richard Bentley \& Son publishing house, in a two-volume collection of Linton's most important works. In this essay, Linton takes a conservative stance against modern middle class women who engage in sensualist capitalism through consumption. Linton's moralistic views on consumption in this paper are very useful in understanding the push backs against sensual capitalism during the nineteenth century and is a great juxtaposition to Zola's novel The Ladies Paradise, as well as the success of the Great Exhibition. The Girl of the Period will also prove useful in establishing an understanding of morality in the late nineteenth century.

The best way to determine the core of conservative arguments and their push against unbridled and sensual capitalism, would be by defining modern consuming middle class

${ }^{146}$ Anderson, 72. 
women at the time. For Linton the modern woman is described as being: “...a creature who dyes her hair and paints her face...-a creature whose sole idea of life is fun; whose sole aim is unbounded luxury; and whose dress is the chief object of such thought and intellect as she possesses..."147 This quote is an embodiment of sensual capitalism. To begin, the modern woman is a character who pursues the accumulation of all material things which are otherwise considered "luxuries". The modern middle class women had little care for the use value, exchange value or historical and cultural symbolisms in the object of their consumption. Instead, they pursued "unbounded luxury" for their own sensual gains and engaged in the type of sensual capitalism Zola wrote about. The previous quote is also very synonymous with the scenes that take place in The Ladies Paradise, which is why it is interesting to see how Linton opposed writers such as Zola, and the very consuming "modern" women he was writing about. For example when talking about "unbounded luxury", this can be linked to one instance in particular from The Ladies Paradise, when women are described as being "helpless", "excited" and "greedy eyed"148 when they are in Mouret's department store, looking at the surplus commodities surrounding them. In another scene, our main protagonist Denise Baudu walks into The Ladies Paradise and stumbles, "straight into Mouret's display; and though she was scared, the woman in her was aroused, her cheeks were flushed, and she forgot herself as she gazed at the blazing conflagration of silks." ${ }^{149}$ Here Zola accurately describes the spectrum of pleasurable emotions female consumers experienced by walking into a department store. It is these types of emotions and pleasures that the modern consuming woman would have been exposed to, when she shopped in department stores at the time.

\footnotetext{
${ }^{147}$ Linton, The Girl of the Period, 2.

148 Zola, The Ladies' Paradise.

149 Zola, 49.
} 
Further on the sensual experiences granted to female consumers in The Ladies Paradise, Zola depicts department stores as being flamboyant consumption spaces. In another scene fabrics are described as being arranged in "avalanches, as if they had fallen at random from gaping shelves... blazing with the most flamboyant colours." ${ }^{150}$ These displays made the consuming middle class women feel "tormented by desire and doubt" $" 151$, until they became "intoxicated with it." 152 If we take into consideration Marx's earlier ideas on the senses and how they are restricted in capitalism, then we can see from Zola's novel and my analysis of Linton's writing on the modern woman thus far, that this is not entirely the case anymore in late nineteenth century. It is true that the senses were not as targeted in early manifestations of consumer encounter before 1851. Consumers were not exposed to extravagant displays and a surplus of commodities, and instead ventured out to the cities only when they had a purpose. The senses were regulated and all sensuous pleasure were restricted. The only exception to this being, the engagement of sensual pleasure in the privacy of one's home. With the rise of department stores and capitalism, we see the late Victorians reawakening their senses and experiencing sensual engaging pleasures in a public setting. To be more exact, this sensual awakening could only be attained from exposure to extravagant department store displays and consumption. The shop owners during the late nineteenth century were aware of these "experiences" they were providing their customers and capitalised on those senses. The reawakening of the senses, which bourgeois writers such as Marx classified as being "primitive" is exactly the type of social, sensual awakening that the conservative Victorians are afraid of. Writers such as Linton were afraid that through sensual awaking and consumption, respectable middle class women of society would regress into

\footnotetext{
${ }^{150}$ Émile Zola, The Ladies' Paradise, Oxford World's Classics (Oxford ; New York: Oxford University Press, 2008), 48.

${ }^{151}$ Zola, 79.

${ }^{152}$ Zola, 83.
} 
uneducated, brutish and primitive versions of themselves ${ }^{153}$, who would become no different to the painted modern women. In other words, character types who disregard all social and historical morality for the purpose of gratifying personal sensual needs and wants. It is during this transition that women become full consumers and cease being producers, or more accurately, reproducers in the sense of nurturing the family household. Middle class women being capitalist consumers essentially went against all Victorian standards and expectations of women.

On a similar but different note, there is also evidence of a fear of the blending of classes emerging. As noted in my earlier discussion of the Great Exhibition, the rise of department stores and competitive consumer prices made it so that occasionally even lower classes could engage in some forms of consumption which in previous decades would have been impossible. Although cyclical depression and the Great Depression, dampened the ability of the lower classes to enter consumer markets such as the department stores, it was not utterly impossible. Further, with the creation of the role of shop girls, which blended the lower and middle classes in a work environment, it was possible for a lower class girl to raise her station through her employment in successful department stores. ${ }^{154}$ This meant that consuming middle and upper class women and men would have been in contact with women of lower classes which sparked a lot of unease amongst the middle and upper classes. This contact between these classes in a public setting would have been socially unlikely in the previous decades, unless they came into contact with servants associated with their own households. It is this much more casual exposure to the lower class and the engagement in so called "primitive" sensual consumption that had the power to regress and blend the lower and middle classes -- a possibility which terrified bourgeois conservatives at the time. This can

\footnotetext{
${ }^{153}$ Linton, Ourselves, Essays on Women.
}

${ }^{154}$ Rappaport, Shopping for Pleasure. 
help explain why Linton and other conservative writers were so fixated on writing about morality. It was essentially an attempt to reinstate public morals and dissuade respectable middle class women from exposing themselves to immoral consumption be it in the form of literature, commodity consumption, fashion and so on.

Going back to my discussion on the reawakening and exposure of the senses in department stores, commodity fetishism added to the consumer's sensual awakening and manipulated the senses. Commodities were frequently fetishised in order to create an aura of mystification around the commodities, before they engaged in exchange. In The Ladies Paradise, this fetishisation of commodities appear in the form "flesh-coloured fabrics with a satiny texture which had the softness of a blonde woman's skin..."155 The metaphorical use of colour and fabric textures resembling the female naked body are used here to fetishise the commodities within the department store and create an image of sensuousness. Going further, Zola writes that female consumers often saw themselves reflected in the commodities portrayed ${ }^{156}$ which is why they were so tempted to give in to their inner desires and consume the commodities being advertised. By manipulating consumer senses through mystification of commodities, the department stores succeeded in generating a desire to purchase and consume the commodities being presented. Even when it is beyond all rationale to do so. In Mouret's, store the "women pale with desire" 157 when they come into contact with intricate arrangements and displays, some of the female consumers are also described as facing "an irresistible desire to throw themselves into it and be lost." ${ }^{158}$ This notion of giving into the irresistible sensual pleasures is important to note here. Considering that consumption in department stores took place in a public setting, it was considered shameful for a Victorian

\footnotetext{
${ }^{155}$ Zola, The Ladies' Paradise, 5.

156 Zola, The Ladies' Paradise.

157 Zola, 104.

158 Zola, 104.
} 
woman of class to be exposed to sensual feelings. Even more so when she could be witnessed giving in to her sensual desires in front of fellow consumers or onlookers. This is an additional reason for why the modern middle class women who frequented department stores were looked upon with such distaste and were described as being akin to "street-walkers"159, by conservatives.

Returning back to my discussion on commodity fetishism, as I discussed earlier in my paper, Marx noted that the mystifying qualities of a commodity are lost upon their exchange, this can help explain why the 'return' system on commodities was so prominent in Zola's novel, and English department stores at the time. The consuming women were only interested in the mystifying properties of a commodity, so long as it engaged with their senses and supplied them with gratification upon purchase. This is why when we consider the notion of giving in to the irresistibility of commodities, we can see a fight brewing within the mind of a consuming Victorian. This is a fight between keeping morality in check, or, surrendering to all sensual delights. Once the commodity is purchased and within the hands of the consumer, as Marx clearly stated in Capital, the commodity loses all mystifying and sensual properties. It becomes just simply a commodity, an object of past desires and experiences. This demystification of the commodity could be the reason for the popularity of returns at the time. Zola also picked up on the importance of return systems in his novel. I point to a particular example from the novel in which the character Madame Guibal tells a fellow female friend about how "convenient the 'return' system was; 'previously, she never used to buy anything, whereas now she occasionally yielded to temptation.' In fact, she returned four articles out of five..." ${ }^{160}$ What this quote tells us is that from Zola's observation of the Bon Marche in Paris, it was not uncommon to witness women giving in to the temptations and mystifying qualities

\footnotetext{
159 Rappaport, Shopping for Pleasure, 207.

160 Zola, The Ladies' Paradise, 2008, 247.
} 
of a commodity by engaging in their purchase, only to later discover that the commodities purchased were not actually needed or desired. The same was true of English department stores, as outlined by historians such as Rappaport and Gurney. This is a turning point in the understanding of commodity manipulation and fetishisation in late nineteenth century because it presents early examples of sensual consumption which arises in the literary sphere, rather than political economy. This analysis of Zola's political economy proves that below the surface The Ladies Paradise was a political economic text which exposed its readers to political economic discussions.

Going back to Linton's original statement regarding "luxuries", Linton ultimately raises the question, what is considered as morally acceptable consumption? Linton never clearly identifies what is acceptable, and neither do household economy guides of the time, such as The Book of Household Management by Isabella Beeton. One thing is clear however, any form of consumption which engages with the senses, concerns women, and takes place in a public setting, is considered improper. This is why the return system, proposed a strong ultimatum to any Victorian woman who found her consumption questioned. The returns system was an excuse and a form of validation of consumption. If the Victorian woman's consumption was deemed improper by her peers or her husband she could validate and defend herself by proposing that she simply return the article purchased to the store free of consequences. It enabled a means for women of all classes to let themselves embrace sensual consumption whilst defending their habits and morals. Lastly, it allowed women a certain degree of liberty in that sensual consumption could take place free of consequences. Sensual consumption understood in this way can be seen as being a form of women's emancipation, which is likely a key reason for why conservative writers were so against it. I will discuss women's emancipation in greater detail in my final chapter, as well as unite my overall thesis argument. 
To conclude my discussion on Linton's definition of a consuming woman, I want to point out one small nuance. It is clear from Linton's essays from The Girl of the Period, that Linton was aware of the moral downfalls of the modern consuming middle class women, in particular in her characterization of their over-indulgence in luxuries. But, she admits later in an 1883 article titled Our Small Sins that this is not solely due to the immoral sensual consumption committed by modern women. Instead Linton criticises the whole nation for turning towards "self-indulgence and luxury." ${ }^{161}$ Linton claims that imprudence is to blame for women's sensual consumption and that this is a problem which concerns the whole nation. ${ }^{162}$ Considering that towards the late nineteenth century more people were consuming commodities in general, and were thus more exposed to all forms of capitalism including the sensual, Linton is partially correct here. Linton was potentially arguing against capitalism here, not just sensual capitalism. An over-indulgence in all forms of consumption and focus on societal imprudence meant that more Victorians were engaging in practices which would have otherwise previously been considered as un-virtuous. ${ }^{163}$

In her essay Linton acknowledges that middle class women in Victorian society were encouraged to exercise prudence when purchasing items for themselves and the home. But she draws the line where prudence is concerned, by stating that women's pursuits of material goods often times, come before family needs. Linton goes further by arguing that middle class women pursuing bargains and consumption on the basis of prudence whilst foregoing family needs, actually act with imprudence. "To barter home and love and children for the luxuries that can be done without, and that do not help the life or the soul in any way, is not prudence, but utter and entire selfishness." ${ }^{\prime 64}$ Linton essentially outlines a concrete argument

\footnotetext{
${ }^{161}$ Linton, Ourselves, Essays on Women, 202.

162 Linton, 202.

${ }^{163}$ Linton, The Girl of the Period, 202.

${ }^{164}$ Linton, Ourselves, Essays on Women, 204.
} 
here against capitalist consumption in general. For Linton capitalist consumption breaks down the existing social and moral relationships in a society, because individuals choose to pursue personal desires and consumption over their relationships. By teaching middle class women to be prudent with their purchases, it means that worker wages can be lower and families can get by on less. In this sense, prudence is a useful and necessary skill for a housewife. Linton voices a concern regarding prudence, which considers women spending household allowances on themselves rather than family. Linton addresses this by saying that prudence when pursued for personal consumption is not prudence in the slightest, but rather "selfishness", thereby highlighting the problem of women's purchase and consumption at the time.

In this section, Linton to an extent defends the consuming women, by stating that their consumptive habits are a fault of the country's political economy. Considering the antifeminist tone of her other works and even other sections of The Girl of the Period, it is surprising to see some of her feminist ideas shine through here. Further, the previous quote are clearly indicates that Linton is not only discussing political economy, but in fact criticising it publically, which is not too different to what Zola was doing in The Ladies Paradise. At length these two writers are both writing about political economy of the nineteenth century, and are exposing more readers to the existing political economic discussion and issues taking place. In Linton's case the purpose of her writing is to re-instate social morality and respectability in middle class women's consumption, which for Linton can only be achieved through revolutionising literature.

Linton argues in a newspaper article for the Sheffield Daily Telegraph in 1890, that literature has been plagued by writers such as Zola for too long, and that there needs to be a purge: "The free literature of the past would be an outrage on the present day...The truth is that the only means of purging society of filthy and vicious literature is the restraining force 
of a strong, healthy, public opinion ...."165 In order to re-instate social morality, the literary sphere needs to be purged of writers such as Zola, who have little regard for social manners and write about "filth"166. As I stated earlier in my thesis, Linton's writing proves that Zola was thought of as a threat to Victorian morality, because he wrote about realism and unbridled capitalism. Linton clearly fears that society will regress if there are no sufficient morals in place. At its core, Linton is fearful of middle class women and young readers becoming morally implicated through exposure to immoral literature. Linton argues that to protect these readers from exposures it is necessary to censor literature by establishing "locked bookcases" 167 behind which all immoral literature could be kept. Although, Linton later acknowledges that this would be no more effective than doing nothing, because at their core women are curious and prone to consumption. ${ }^{168}$ For Linton the engagement with the senses through consumption of literature and commodities is not a means of activating the senses and progressing the human senses. Instead, she takes a stance on sensual consumption which might be more comparable to Marx, in that the senses are primitive and something that ought to be hidden behind closed doors rather than shamefully exhibited in public.

With my points on Linton and Zola thus far, I have demonstrated how both Zola and Linton in their writing, are ultimately discussing consumption, which by modern standards and the theories I am applying in this paper, fall under political economy, a field of study which was closed off to middle class women such as Linton and writers like Zola at the time. These two writers are in essence an example of two people who managed to publicly discuss political economy, in a way which was understood and accepted by the public, without being ousted as publishing politically charged papers/novels. It is in writers such as Linton and Zola

\footnotetext{
165 'Summary Of News', Sheffield Daily Telegraph, 10 January 1890, https://www.britishnewspaperarchive.co.uk/viewer/bl/0000250/18900110/008/0004 . 166 'A Woman's View Of Zola'.

167 'Summary Of News'.

${ }^{168}$ Linton, Ourselves, Essays on Women.
} 
that we get to see how real consumption and production politics was discussed in the nineteenth century.

One thing is certain from reading the works by these two popular nineteenth century writers, there was undoubtedly a political discussion taking place beneath the surface. In Linton's case, she acknowledges that Zola who was popular amongst many female readers, wrote about political charged and inappropriate topics. Any women who declared herself a reader of Zola would undoubtedly put her reputation on the line. This is because “...a family's respectability and social position depended upon the idea that the middles-class wife and daughter remain apart from the market, politics, and public space..." ${ }^{\text {169 }}$ By engaging in the consumption of politically charged novels, respectable middle class women were inevitably engaging in a political discussion. Linton's concerns do not stop there, the consumption of sensual commodities in department stores also put the women's reputation on the line. As I have shown, this is largely because the middle class women gained particular liberties when they consumed in department stores. They were free to roam the store and streets unsupervised and could engage in unlimited sensual pleasures. It is this emancipation of women's rights and liberties which Zola and convective writers alike were so concerned with. This is most likely why the published so many negative reviews against Zola despite his growing popularity and demand.

On the topic of Linton, there is one more interesting point I wish to point out. Linton herself was a free woman. She carved a space for herself in a patriarchal society through her publications of anti-feminist work. Writings which consequently had the potential to rob other women of their liberties. Likewise, despite her discussion on middle class women having to be separate from politics, her own writing is obviously very politically charged. Her

${ }^{169}$ Rappaport, Shopping for Pleasure, 6. 
entire character is quite contradictory and shows the ultimate difficulty women who desired liberty faced at the time. Liberty could be achieved but under very particular terms, in Linton's case it was through her transition to anti-feminism. By taking an anti-feminist stance, Linton successfully carved a space for herself in a patriarchal society and gained economic and literary freedom which many other women could only dream of.

The growing importance of the women's rights movement during the late Victorian era and how this movement connected to the question of economic, consumption, and sensual capitalism was also at play here. Linton writes in Our Small Sins, there is no one who wanted women's emancipation more than the consuming women themselves. Linton expands on this by stating that:

No one but women themselves know how bitter this dependence is to them. Many a wife even after long years of marriage...feel bitterly that nothing is theirs, that it is not their own. It is their husband's; and if in their confidence you may hear them passionately exclaim, "Oh! That I had money of my own! However small, if I had only something, and was not obliged to go to my husband for every pair of gloves or yard of ribbon! ${ }^{170}$

The owning of property, however sensual, small, or obscure fostered a spirit of enfranchisement in women that Linton feared. The growing importance of the women's rights movement during the late Victorian era and how this movement connected to the question of economic, consumption, and sensual capitalism was clearly at play in reactions to Zola.

But, as I have argued throughout, this exposure to politics was already taking place through literature, as is the case with The Ladies Paradise. It is precisely because The Ladies Paradise and topics on consumption were not considered as political economy by mainstream writers at the time such as Bagehot and Marx that Zola, Linton and their female readership were able to participate in this discussion, largely without interruptions. Engaging in political

${ }^{170}$ Linton, Ourselves, Essays on Women, 228. 
discussions in literature fell outside of the scope of the political economy canon for most late Victorians which is why women could be pardoned, and simultaneously as Linton has shown, condemned on this matter for reasons of sensual capitalism and immorality. But middle and lower class women acting on these political economic interests, would have been a very different matter. The late Victorians were under the impression that women upon gaining rights to voting and parliament would dismantle the logic of patriarchy and with it society as they knew it, destabilizing respectability and perhaps Englishness itself. At the core of the suffragette issue was women's threat to constitutional patriarchy and power. Another paper supports a similar claim stating that:

It is when the ladies begin to ask for votes, for seats in parliament, and to be allowed to settle the income and foreign policy of the country that they find the gallantry of the Englishman is only skin deep, and his idea that his is the superiors sex obdurate...While we still keep women in "subjection," and think them more in their place at homes, or "teaching the orphan boy to read, the orphan girl to sew," than when making speeches about politics or unsavoury social questions... ${ }^{171}$

It is clear that patriarchy was at their limits in determining the rights of women as well as their role in society, all the while disregarding the fact that women were an important asset in a capitalist economy, without whom the system wouldn't work otherwise. Likewise, considering the Great Depression which was taking place around the same period at the late Victorian women's rights movement, it was against all interests for the English economy to disregard women's rights and their effect on the economy.

The late Victorian women's right movement is at the root of the Victorians hesitancy of sensual and unbridled capitalism. By engaging in sensual capitalism in public spaces women gained newfound liberty and rights which they previously would not have had. It was also through the reawakening of the senses that motivated women to engage in sensual capitalism. The late Victorians were fearful that the pleasure granted through sensual

\footnotetext{
171 'Women's Rights Progress', Essex Herald, 9 October 1882, https://www.britishnewspaperarchive.co.uk/viewer/bl/0001635/18821009/057/0004.
} 
consumption would corrupt the minds of respectable women and expose them to indecencies. In the case of The Ladies Paradise, sensual consumption took place in literature and exposed women to political economy.

Although the suffragettes greatly wanted to gain voting rights, this is not the only thing they hoped to achieve through their suffrage, they also wanted to attain improved female rights in law, employment, marriage and education. Linton was one of the many conservative writers who frequently bumped heads with the popular suffragettes at the time on women's rights to education. In one article Linton found herself in a disagreement with women's suffrage activist Millicent Fawcett regarding women's higher education. For conservative writer Linton, women should not look to attain a higher level of education or career success, due to moral impairment, despite her own peculiar background. Fawcett on the other hand argued that this was a necessary right as it would constitute "as a means of earning a livelihood." 172 This notion of "livelihood" is a very important point to consider because when we keep the Great Depression in mind, many working women were considerably more driven to earn enough income to cover their basic needs, and if possible improve their quality of life. These working women, often were more incentivized by promise of good stable wages, than they were by social morality, as was the case with the department store shop girls. Their in-between positions as being associated with unbridled consumerism on the one hand and workers who played a key role in the economy made them provocative and suspect figures for thinkers on either side of the sensual capitalism debate.

From the mid-late nineteenth century many women of lower middle classes, and a few fortunate women from the working classes found employment in the department stores and shops around England. The first notion of a "shop girl" came into existence around the 1880s

\footnotetext{
172 'Women On Women's Movements', Bicester Herald, 5 November 1886, https://www.britishnewspaperarchive.co.uk/viewer/BL/0002292/18861105/104/0007?browse=False.
} 
as an embodiment of shifting women's working conditions and freedom. The shop girls often lived away from their homes “... and occupied a relatively unsupervised sphere of social interaction, and therefore possessed a certain degree of freedom of action both at work and in their leisure practices. As a result, the figure of the shop girl organized a number of lateVictorian middle-class anxieties over sexuality, morality, and class position." ${ }^{173}$ The shop girls were often morally ostracized because of their positions in the department stores.

Aside from their roles as shop employees, the shop girls embodied more than their simple shop clerk roles. Similarly to the ways in which women were sought out by shop owners for profits, the shop girls were too sought out. But, this was for a very different reason. Female employees were sought out because the shop owners:

"...imagined they might more effectively serve the needs of the women on the other side of the counter. This assumption was predicated on a conception of feminine consumer desire that incorporated identification through fantasy, such that when a shop assistant employed behind the counter or in the showroom displayed merchandise for customer, she embodied the projected fantasy image of possibility even while remaining differentiated from the consumer through her status as seller rather than buyer of goods." 174

The shop girls were hired for the purpose of being vessels of sensual capitalism. Their purpose was to project an experience of luxury and desire through their appearance and proximity with the commodities within the store to the consumers, thereby sparking their awe and hunger to consume. As Lise Sanders reiterates, "women on both sides of the shop counter were imagined to participate in a panoramic vision of glamorous and luxurious consumption." ${ }^{175}$ Further, the positioning of the shop girls meant they also experienced a desire to sell commodities due to personal identification in the wealthier shopping women, thereby making the shop girls agents of sensual capitalism as well as consumers.

\footnotetext{
173 Sanders, Consuming Fantasies, 21.

174 Sanders, 23.

175 Sanders, 55.
} 
Aside from that, the shop girls were also symbols of commodity fetishism and desire. The bodies of the shop girls "were offered up to consumers both as sexualized recipients of male desire and as mediators for female consumers' fantasies." ${ }^{176}$ In Zola's novel the shop girls were fetishised and commodified for the purpose of creating sensual experiences and persuade consumption. The purpose of the shop girl was to entice women to engage in pleasurable consumption through jealousy and their power within the department stores. Being situated on the opposite end of the counter, the shop girls positioned themselves closer to the commodities which stimulated the senses, thereby making the consumers envious of the shop girls.

The shop girls are an important puzzle piece to understanding sensual capitalism and how department stores operated. On the surface, the shop girls represented freedom, luxury, opportunity, as well as class elevation through increased marriage prospects and wage. But, below the surface, they were ostracised morally for their liberty, exploited for their labor and gender. They were agents of capitalism and at the same time, were consumers of sensual capitalism. Despite the relevance of the shop girls and their obvious importance in sensual capitalist. They are an example of a group of people who are obscure and rarely heard about in Victorian society, despite their undeniable importance in the functioning of the department store. The shop girls are also synonymous women's role in capitalism in general. Capitalism relies on consumption, which I have shown was for the most part in the late Victorian period was driven by women, and yet their engagement in sensual consumption or unbridled capitalism was frowned upon.

I have already alluded to the various anti-feminist arguments presented by Linton throughout my paper, but I have yet to say the impact that she had on her readership or what

${ }^{176}$ Sanders, 55. 
her direct impact is in late Victorian political economy. Whilst her essays such as The Girl of the Period gained her national recognition, popularity amongst the conservatives, and solidified her career in journalism, Linton essentially ignited the women's question on a new level. After the publication of The Girl of the Period, several magazines and articles who were apathetic with the women's rights cause, "began contributing to the debate that this one essay alone incited." 177 Thereby, helping the women's rights movement generate more controversy and discussion.

But, Linton was not just an antifeminist. At times it even appeared as though Linton was supportive of women and their cause, as was the case with her helping aspiring female writers. Following Linton's success in journalism many aspiring female journalists emulated her writing style and reached out to her asking for her advice in all manner of career related things. ${ }^{178}$ In an article by Andrea Broomfield, Broomfield quotes Helen Black who wrote in Notable Woman Authors that "a score of young authors ... owe their success and a deep debt of gratitude to her!" 179 Whilst Linton took an antifeminist stance in her work and often embodied conservative view regarding women's rights, such as education and employment, Linton ultimately helped inspire many female writers.

Of the similarities amongst the female writers who came after Linton, most notably was the similarity with which the writers were capable of inciting public outrage and debate. ${ }^{180}$ As I explained earlier in Linton's biography, writing papers with strong opinions which incited public outrage or controversies, was a trademark of Linton's from the early stages of her career. Linton essentially taught writers how to write controversial papers which would entice public readership and discussion. In this sense Linton and Zola were the most

\footnotetext{
${ }^{177}$ Andrea L. Broomfield, 'Much More than an Antifeminist: Eliza Lynn Linton's Contribution to the Rise of Victorian Popular Journalism', Victorian Literature and Culture 29, no. 2 (2001): 267-83.

${ }^{178}$ Broomfield, 268.

${ }^{179}$ Broomfield, 280.

${ }^{180}$ Broomfield, 280.
} 
similar. They both knew how to capitalise on and create public debate and controversies thereby, increasing their readership and getting more people to engage in discussions from their writings.

Through Zola's writing on realism and political economy, Zola attracted the attention of Linton, thereby engaging her in political economic debate. A debate which both writers would otherwise be barred from due to social, moral, gender and class limitations. Linton then, further exposed readers to Zola's political economy through her critiques regarding The Ladies Paradise and Zola's other works. The women's rights movement by extension, became enveloped in this political economic debate through Zola's and Linton's discussion on political economy. All of these examples and events have shown how literature is the front and centre on the political economic debate.

I have shown in this chapter how Linton ultimately was writing politically charged literature and was pushing against sensual consumption, particularly in her arguments against Zola and The Ladies Paradise. I have also defined what it meant to be a modern consuming woman and how sensual consumption took place. One of the core conservative critiques of Zola and sensual capitalism, revolves around women's emancipation and its connection to the Victorians hesitancy in embracing sensual capitalism. In the following chapter I will discuss women's power through household economies as well as the drivers of consumption, for the purpose of determining the role of women within household economies and the British political economy at the time. 


\section{Chapter 3: Household Economy}

\section{The Role of Women and Household Management}

The purpose of this section is to determine the role of the middle class women in Victorian households and economies, for the purpose of establishing a framework through which I can then discuss the push against increased women's rights. By establishing the role of middle class women in household economies and illustrating the ways in which middle class women managed and used money, I can then begin to analyze why Zola's political economy in The Ladies Paradise, was so relevant to women's lives at the time. Further, I will be able to clearly show how Zola's political economy was relevant to the political economy at the time, through my analysis of drivers of female consumption.

Up until thus far I have discussed how women of all classes were the primary consumers in late nineteenth century, but it is not entirely clear why or how this was the case without looking at Victorian household economies.

In a book on proper Victorian etiquette and household management by Isabella Beeton, titled Book of Household Management (1861), the author outlines how respectable Victorian middle class women managed their household economies and what it meant to be a good housewife. Although etiquette manuals such as Beeton's cannot give a clear indication of the adoption of the practices they spoke of, or of the scale on which they were adopted, etiquette manuals are still useful historical documents when analysing societies over time. Historically, etiquette manuals were written as a reaction to people not following supposedly understood societal rules, as well as to reinforce social class and gender. These manuals are an example of an attempt to discipline society and reinstate moral values. In the case of Beeton's book, the purpose was to educate women about their role and place in a household. 
Although Beeton does not provide a concrete assertion that women did control the household economy, she does outline some desirable traits of a housewife that are bound up in what me might think of as the household political economy. For example, a good house wife is one who can make her husband and children happy, whilst keeping her virtue intact and completing all necessary household duties. Traits such as, "rising early, frugality, choice of acquaintances, hospitality, good conversation skills, good temper, suitable fashion and dress"181 are examples of highly desirable traits in a good housewife and key skills in managing a household. This speaks to a kind of measured consumption for women of the household: engaging in fashion but with restraint and frugality. In regards to economy, Beeton is quite clear that individuals of all class levels need to learn how to successfully manage their money in hopes of getting by in life. The housewife is crucial in this equation because she is the one who needs to keep track of all of the household spending in her leger. Further, when it comes down to paying the servants, furnishing the house, or even purchasing personal necessities, it is down to the woman of the house to approve and record all of the spending. ${ }^{182}$ This supports my claim up until thus far, that in Victorian homes, it was the women, particularly married women, who were in control of the spending and held the most consumer power. In regards to personal consumption, Beeton also clearly states that, "To be a good housewife it does not necessarily imply an abandonment of proper pleasures or amusing recreation..."183, and that a mistress should be properly attired for all occasions and should have clothing which is both tasteful and the best available means for her allowance. In this particular guide, Beeton appears to claim that to a certain degree of women's consumption is not only to be expected, but it is also required. Likewise, by requiring women to be properly attired for all manner of occasions Beeton promotes utilitarian consumption -- more on this

\footnotetext{
${ }^{181}$ Isabella Beeton, The Book of Household Management ... (Ward, Lock, \& Company, 1861), 81.

182 Beeton, 84.

${ }^{183}$ Beeton, 80.
} 
later in this chapter. Reading Beeton's guide brings to mind the question: where is the line drawn between necessary consumption for the purpose of proper household management versus personal and sensual consumption. My analysis is that when personal consumption transcends basic needs and engages with the primitive senses of touch, smell and taste, it becomes sensual consumption, which was deemed morally improper. Going back to my discussion on Marx's understanding of sensual capitalism, for Marx the primitive senses were something to be ashamed of, whereas the cultivated senses such as reading, were evidence of the development of human kind. But, this argument can be taken further. The so-called "primitive" senses were often gendered and were attributed to women. Hence, when discussing the primitive senses as being shameful, political economic writers at the time ultimately gendered the production and consumption sphere by determining that production which was considered a masculine trait, was rational and applied cultivated senses. Whereas as consumption, which was feminized, applied "primitive" senses and was therefore: barbaric, irrational, immoral and shameful. This contradicting approach to consumption and production which are interlinked and dependent on each other for the stabilisation of capitalism, alludes to the reasons why the Great Depression was perpetuated by over production and under consumption. It also demonstrates to what extent the late Victorians were eager to disregard consumption and along with is sensual capitalism, despite the capitalist system requiring it.

Going back to Beeton, on a different note, there are four observations which can be made by analysing Beeton's book. Firstly, the book is over one thousand pages long, but only about twenty of those pages are directly related to the management of money and women's consumption. The rest outlines the correct dining and cooking practices of a good household. This highlights the extent to which a women's consumption mattered when it came to management of the household economy, as well as outlining the desired features of a 
housewife. Secondly, despite Beeton passing away in 1865, her book "continued to be a best-seller" 184 for many years after her passing. This means that Beeton's book on household management became a staple guide for many Victorian readers, thereby amplifying the uptake of Beeton's vision of good management of the household economy during the midlate nineteenth century. Thirdly, Beeton's book legitimises the need for women to engage in the outside world and consumption, despite the conservative push backs against shopping spaces and consuming women during the late nineteenth century. For the purpose of legitimizing female consumption in the public sphere and normalizing it, during the late Victorian period shopping guides existed for all class levels, to normalize and moralize about shopping. ${ }^{185}$ These guides aimed to teach women how to consume in a more morally acceptable way as a means of legitimizing the presence of women in a public consuming space as well gradually establishing increased women's rights. Lastly, Beeton clearly outlines that it is the housewife's or the mistress's role to manage a household economy, not an unmarried woman's. This is an important distinction as it shows who holds the most social and economic power. Linton makes this distinction clearer by stating that, "it is the married woman -who, moreover, bears the purse and possesses the social influence..."186 This mattered in so far as determining who the primary sensual consumers were and for whom the markets were tailored. Conversely, an upset in the consumptive patterns of women could affect the institution of marriage itself in Victorian society. The stakes of consumption discourse in late-Victorian society were about the maintenance of British constitutional monarchism in the form of male-only voter enfranchisement, on the one hand, and the stability of middling-class led patriarchal marriage and household as the socio-economic unit of the nation. Though not explicit, these topics were deeply bound up in questions of political

\footnotetext{
${ }^{184}$ Beeton.

${ }^{185}$ Rappaport, Shopping for Pleasure, 110.

${ }^{186}$ Linton, Ourselves, Essays on Women, 160.
} 
economy. Linton gives evidence for this in one of her essays in Ourselves, confirming that it was the married women who were sought after by traders and establishment, because they possessed the household allowance and had the most influence due. ${ }^{187}$ As Britain's economic prosperity appeared to rest more and more on consumerism, it begged the question as to if power over the household "domestic" economy would have to translate to power within domestic (ie/ national) politics. The drive to obscure or suppress knowledge of the link between the two is perhaps the most characteristic element of late Victorian political economic discourse and yet we can see how this drive was subverted in discussion around fiction and its effects in the case of Zola.

\section{Drivers of Female consumption}

Thus far I have established that women were in charge of household economies and that to an extent women's consumption was not only normalised, but expected. On the other end of the spectrum, I have presented arguments centred on women's consumption expressed through information about the senses, which were often described as being irrational and emotional. But there is more to the story for why women consumed commodities. In this section I will discuss the drivers of female consumption during the late nineteenth century, as well as the relevant consumption theories. The purpose here will be link criticism of women's consumption choices with my analysis of the late Victorian push against the women's rights movement. Throughout I have shown that people purchased commodities for sensual purposes and comfort, but there are more drivers of female consumption. In this section I will outline five additional drivers of female consumption. In this particular order I will address: 1) imitation and emulation, 2) envy, 3) bargains, 4) attention and, 5) fashion.

${ }^{187}$ Linton, Ourselves, Essays on Women, 160. 


\section{Imitation and emulation}

Late Victorians assumed that imitation was a strong cause for why women consumed commodities. Women imitated each other for a number of reasons, one of which was fashion and beauty. The modern consuming woman, who was otherwise also known as the "demimonde" had a painted face and wore the best fashions. ${ }^{188}$ This fashionable and luxurious female character exhibited splendour, wealth and beauty luxury that many women envied and desired. Many women imitated each other's styles in an attempt to attain beauty and luxury. Although the "demi-monde" women were often imitated by female consumers, they were not socially accepted by the conservatives, as these type of women often exhibited signs of bad characteristics such as:

"...slang, bold talk and general fastness; to the love of pleasure and indifference to duty; to the desire of money before either love or happiness; to uselessness at home, dissatisfaction with the monotony of ordinary life, horror of all useful work; in a word, to the worst forms of luxury and selfishness." 189

A woman who pursued and imitated the "demi-monde" queens was seen to lead herself down a path of scandals and immorality. Regardless many women exhibited feelings of envy and the displayed a desire to imitate such women.

Aside from imitation of fashionable women, imitation also occurred amongst women of the same class and social background. In a scene in The Ladies Paradise, an upper class lady shows to her friends a Spanish scarf which she proudly acquired for the price of thirty francs, to which her friends reply is lovely. ${ }^{190}$ A chapter later, we encounter the same lady running into a friend to whom she showed her scarf previously and exclaims, "I

\footnotetext{
${ }^{188}$ Linton, The Girl of the Period, 5.

189 Linton, 5.

${ }^{190}$ Zola, The Ladies' Paradise, 2008, 82.
} 
say!'...'you're looking at scarves and veils just like mine.' ${ }^{191}$ We then learn that this friend was tormented by the design of the scarf that her friend purchased earlier in the novel and wanted one for herself. For this reason she went into The Ladies Paradise in secret to procure one of similar design for herself. From this example it is evident that imitation occurred within the same class levels, and that women's consumption habits were driven by imitative reasons, as well as sensual reasons.

But imitation was not just something that occurred in the middle and upper classes, it extended to the lower classes too. In the novel, "the salesgirls were jealous of well-dressed customers, ladies whose style they tried to imitate." 192 The salesgirls are described as wanting to copy upper class styles for the purpose of rising their position in life and to feel beautiful. This exhibits signs of both imitative and emulative consumption. As explained by Veblen, emulation is a form of consumption in which the lower classes copy the consumption patterns, lifestyles and habits of the upper class for the purpose of trying to elevate their position and class. Imitative consumption on the other hand, as explained by Colin Campbell is when consumers of all backgrounds copy each other's consumption patterns or styles for the purpose of self-pleasure. Although The Ladies Paradise depicts fictional scenarios, such forms of imitation and emulation frequently took place in late Victorian society, thereby making Zola's novel all the more important and relevant when looking at sensual capitalism and consumption. At play in Zola's novel and the reaction to it was the fear that the lowerclasses would start emulating their social superiors and blur the lines of social distinction on the one hand and run themselves into financial ruin on the other. Moralizing about consumption was one way that "respectable" writers meant to keep both of these elements in check.

\footnotetext{
191 Zola, 110.

192 Zola, 82.
} 


\section{Jealousy and envy}

Following on from imitation, consumption prompted through jealousy was undoubtedly one of the most impactful drivers of female consumption at the time, evidence for this can be seen in both Linton's and Zola's writing. But the manner in which women were jealous of each other had some differences. This matters to political economy because it shows how instead of understanding the social drivers behind women's consumption, writers at the time, interpreted this important social and economic exchange as being driven by petty female emotions. Going back to my previous point regarding envious sales girls engaging in imitative consumption, the consumers themselves often envied the sales girls too. There is evidence in the novel of lower middle class women expressing a desire to imitate the styles of the sales girls, but due to their financial circumstances not being able to do so, "poorly dressed customers, lower middle-class women, felt even more sourly jealous of the salesgirls, the girls dressed in silk whom they wanted to treat like servants each time they made a purchase costing a few pence." ${ }^{193}$ Class plays a major factor in The Ladies Paradise, and in this example it can been seen how the sale girls fell into a social grey zone, by this I mean that they no longer fell into the previous class restricted categories. This would frustrate customers who felt entitlement as a middle and upper class consumers, thereby leading to the mistreatment of female department store employees. This shift in purchasing power and class power often became senseless because in the department stores which followed capitalist modes of consumption and production, consumer class were irrelevant so long as the shoppers were consistently consuming commodities.

On a more political economy note, this put into question the notions of class. This is mainly because notions of class historically were solidified through consumption. Veblen and

193 Zola, 82. 
Bourdieu write about this extensively in their works. Veblen argued that the upper classes engaged in conspicuous consumption in order to represent their status and wealth to the other classes. ${ }^{194}$ By engaging in conspicuous consumption, the upper classes were seen as consuming all manner of things without any obvious reason for doing so, other than to solidify their social class. Whereas for Bourdieu, class could be solidified through consumption practices alone. ${ }^{195}$ The class that someone belonged to would depend on an individual's tastes and consumer spending. Of course, in my analysis on late Victorian England so far, I have shown that neither of these two theories are exclusively applicable to late nineteenth century consumer spending and habits because, there were many drivers of women's consumption. Nevertheless, these theories help illustrate the complexities between class solidifying consumption and capitalist consumption. In the late nineteenth century department stores, were made more accessible and some of the cheaper commodities were placed at the entrance of the store, for the purpose of including the lower classes in the purchase of commodities. ${ }^{196}$ This meant that consumers could no longer shop in solely a department store, for the purpose of solidifying their class. When approaching the subject in this manner it is possible to see why some of the consumers who wished to solidify their class through shopping, might have been jealous of working class women who were in a position of higher power in a department store setting.

But, jealousy did not extend to the lower and middle classes alone, in another case from The Ladies Paradise, we see middle and upper class consumers competing with each other and becoming jealous over fashions and taste. Linton writes how modern consuming women were often engaged in schemes designed to "outlive her neighbours the extravagance

\footnotetext{
${ }^{194}$ John Brewer and Roy Porter, Consumption and the World of Goods (Psychology Press, 1994), 40.

${ }^{195}$ Brewer and Porter, 42.

${ }^{196}$ Zola, The Ladies' Paradise.
} 
of fashion." 197 Women were pressured to consistently keep up with the fashions and consume in order to stand out and be envied. This notion of "neighbours" means that jealousy was not something that only occurred amongst lower and middle classes. In fact, it was something that transcended the notion of class in general and affected women as a whole.

On a different note, feelings of envy were not just caused by one's ability to afford physical commodities, class difference or wealth, but also the opportunity to engage in sensual capitalism. In Linton's quote about “...the queens of the demi-monde” she sees them as being:

"...gorgeously attired and sumptuously appointed, and she knows them to be flattered, feted, and courted with a certain disdainful admiration ... They have all that for which her soul is hungering; and she never stops to reflect at what a price they have bought their gains, and what fearful moral penalties they pay for their sensuous pleasures...It is this envy of the pleasures, and indifference to the sins..." 198

The key point here being, that women were jealous of other women who could go against the moral and social grain and engage in sensual consumption to their hearts delight. The fact that this is something that Linton writes about implies that Linton was aware of the political economic discussion relating to consuming women at the time.

Women pursuing sensuous pleasures and trying to establish a role for themselves in the public sphere and the political economy, do so through the engagement in sensual consumption. The jealousy that women experience is an example of a petty emotion, beyond which there is a deep feeling of alienation. Alienation of women and their consumption is an example of a real emotion which was a driving force behind political and economic change. Women felt alienated from the patriarchal conception of capitalism and political economy and led the women's rights movement based on this feeling of being alienated. Political

${ }^{197}$ Linton, The Girl of the Period, 2.

${ }^{198}$ Linton, 5. 
economic writers such as Marx, Smith, Bagehot, Veblen and others, attempted to suppress this feeling of alienation through the reinstatement of morality as a means of defining the role of the women as one limited to the private sphere, as well as disregarding consumption and women from capitalist economy in general. The writers who were not disregarding consumption and the role of the women in capitalism, were Zola and to an extent Linton. This is what makes these two writers essentially so important. Real political economic discussions are taking place in the literary world, rather than in the political and economic realms.

\section{Bargains}

Another reason why women shopped related with bargains. As Beeton outlined in her guide, women should aim to purchase the most affordable goods that they can. "The best articles are the cheapest may be laid down as a rule; and it is desirable...that the mistress should herself purchase all the provisions and stores needed for the house." ${ }^{199}$ It is expected of a women to be frugal and search for the best prices on the market when she purchased commodities, and can be a good starting point for beginning to understand why women were sometimes lured into spending through the promise of bargains.

Beeton makes it clear that frugality was a highly desirable trait for a woman during the late nineteenth century, but with this particular skill, time and money are limitations. A housewife who is in search of the best bargains for her household is, according to Zola and Beeton, fulfilling her role as a housewife, and thereby engaging in labor. But this action of bargain hunting is not considered as real useful labor in nineteenth century discussions of political economy. Bargains, are written off as though they are a given and as though women did not have to spend the time shopping around and comparing prices. This further questions Marx's, Bagehot's and conservative writer's interpretation of political economy, in which

${ }^{199}$ Beeton, The Book of Household Management, 84. 
women sensually purchased commodities because they were simply cheap. In order to determine if commodities were cheap or not, the consumers would have had to shop around, and engage in this particular form of labor. The bargain hunting example is simply another example of the ways through which women were vital vessels to the workings of the capitalist system, despite not being acknowledged by political economy.

Returning to my discussion on Beeton, her comments regarding women needing to cultivate frugal skills coincides to an extent, with Linton's opinion in this matter. In The Girl of the Period, Linton observes how women possessed very frugal nature and possessed a strong desire to haggle. Likewise, this desire to purchase commodities if they were cheap, extended to commodities with little to now value for the consumer. In one scene from The Ladies Paradise, Mouret "discovered that a woman could not resist a bargain, and that she bought things without needing them if she thought she was getting them cheaply..."200 This lack of control over spending when faced with a good bargain was a large factor for why many women consumed during the nineteenth century. In his book Gurney writes about conservative writer at the time, Cruikshank, who stated that "the modern female shopper as both gullible and insatiable, rendered almost hysterical by the promise of a bargain ..., ${ }^{201}$ In both of these examples it is possible to determine that for some late Victorian shoppers, the value or use-value of the commodities is not as important as the exchange value. Late Victorian consuming women occasionally purchased commodities simply based on their exchange value alone. Gurney expands on this by explaining the case of store owner William Ablett in 1872, who realized that when there were massive reductions in price "Many shoppers frequently intoxicated by the promise of a bargain, even usually careful buyers 'bought the goods, right and left, using but little judgment, and appearing to care

\footnotetext{
200 Zola, The Ladies' Paradise, 2008, 235.

${ }^{201}$ Gurney, The Making of Consumer Culture in Modern Britain, 39.
} 
only for being served with something or other."202 The opportunity to consume cheaply overrode all insecurities and rational thinking.

Unlike Beeton who claims that it is necessary for a good housewife to cultivate her skills in frugality, Linton however claims that this was not always a positive trait. On the one hand there were a number of business who benefitted from a frugal consumer, but on the other, this skill came with its faults too. For Linton these faults were: cheapness and stingy ways. Linton expands on this in Our Small Sins, when she alludes to the stingy nature of the consuming women, who “...calculates to a fraction the worth of the lace and ribbon on her bonnet, but does not take into account the expenses of her milliner's establishment." 203 For Linton one of the biggest faults of frugal women is their lack of empathy and understanding for business establishments. This is particularly important to consider when keeping in mind a married woman's economic and consumption power at the time.

On the topic of imprudence for business establishments, thrift and good housekeeping were also cultivated for the purpose of suppressing wage demands. By disciplining middle class women's consumption through increased frugality, the consuming woman could bargain and shop around at the expense of other workers' wages. In a sense popular etiquette guides which preached frugality were teaching middle class consumers about how to consume with a capitalist mindset and shaped some of the approaches to consumption at the time. This was a way that the capitalist means of production disciplined ideas of consumption in their mutually constitutive relationship.

My discussion on bargains has shown how women were expected to develop the frugal trait and apply it whenever they engage in any form of consumption. This as I have identified already, according to Zola and Beeton, should be regarded as a form of labor.

\footnotetext{
${ }^{202}$ Gurney, 22.

${ }^{203}$ Linton, Ourselves, Essays on Women, 83.
} 
Further, Linton's comments regarding the stingy nature of women adds more complexity to the notion of bargain hunting as a form of women's labor. For Linton, some forms of labor such as: shopkeepers, is an example of progressive labor which has the potential to add economic and social value to the nation. Bargain hunting on the other hand, which occurs for the purpose of private households, yet takes places in the public sphere, according to Linton is not considered as progressive labor. Instead it is seen as being unnecessary and ultimately harmful to progressive labor types. This dynamic of useful versus useless labor once again puts women and their roles into the limelight, with Linton taking the stance that women essentially do not add anything of value to political economy. On the flip side, Zola essentially argues that the capitalist system requires production just as much as it requires consumption, thereby arguing the importance of women in capitalism. What we see taking place here below the surface is a political economic discussion centered on Zola and Linton. A political discussion which is far outside of the realm of Marx and Bagehot.

\section{Attention}

When discussing jealousy I touched upon aspects of consumption for the purpose of being envied and garnering attention. Similarly to jealousy, envy and attention seeking are seen as being feminine and regressive traits which fall at the bottom of the hierarchy of emotions and senses in political economic discourse where alienation of the feminine traits and women is seen as being progressive.

This was indeed a strong driver of consumption amongst the younger women and women who older age who desired to feel "youthful" again. ${ }^{204}$ But this attention often came with a price and criticism. Whilst it may appear at first glance that many women choose to

\footnotetext{
${ }^{204}$ Linton, Ourselves, Essays on Women, 159.
} 
consume in order to attract male attention or to promote oneself on the marriage market, Linton argues that this was not the case. The modern women or otherwise women described as being the "queens of the demi-monde" would frequently attract negative attention and were often times compared to prostitutes, for their extravagant fashions. With extravagant tastes in fashion and a keenness for material goods, the demi-monde women were considered as possessing poor up-brining, morals and taste. Characteristics which were desired in a late Victorian housewife. For this reason the modern fashionable women, did not fare so well on the marriage market. Instead the fashionable "demi-monde" girls took pleasure in engaging in sensual consumption and garnering social attention. These were the type of women that people, especially men acknowledged “...lived only for balls and dress and pleasure and extravagance.... and are not exactly calculated to make rational wives or profitable partners." ${ }^{205}$ Colin's Campbell's ideas on consumption theory, regarding people consuming purely for the pleasurable reasons, rather than imitative or emulative reasons, apply here. These women consumed commodities simply for the sensual pleasures that it gave them and the attention that came along with such consumption.

\section{Fashion}

The last and possibly most unsurprising driver of female consumption that I will discuss is, fashion. As Beeton outlines in her book on good household management, a housewife had to be adequately dressed to befit her station as well as all manner of activities that she is undertaking. A woman was expected to follow fashions in order to fit in socially, for this reason women were socially required to extent, to consume commodities. A Linton states in one essay, "This is fashion; and none of us dare disobey it; none of us dare go out in the evening with dresses made after the patter of our morning ones, or wear in the morning

${ }^{205}$ Linton, 202. 
low bodices and short sleeves to at least equalize the risk, and inure us to the evening attire without damage..."206 Not following the social rules and etiquette of fashion would mean being improper at best and ostracized socially at worst. This increased specialization and delineation of clothes in the late nineteenth century and meant that "particular clothes were considered to be right and wrong for more and more occasions." ${ }^{207}$ This is why fashion constitutes as one of the biggest reason for why women engaged in consumption.

Thus far I have successfully identified 5 other important drivers of female consumption. When we looking at these 5 factors, combined with sensual consumption and affordability of commodities, it is possible to piece together a narrative which accurately illustrates the motivations behind consumer choice, spending and habits in the late nineteenth century. This analysis of the drivers of late Victorian consumption, is useful when considering sensual capitalism and women's rights, because it proves that there is more to the story than conservative writers made it seem. Women were not just consuming because they possessed poor will power or, were feeble creatures. Instead, there were often very logical and often times very cultural and class embedded reasons for why women consumed in the manner that they did. Not to mention, some guides at the time, such as the one produced by Beeton even legitimised women's consumption by declaring it as a rightful role of a good housewife. When bringing all these factors together, it helps to clearly establish the ways through which women exercised economic power and raises the question; why despite its partial legitimisation, many ultimately sought to repress the rights of female consumers. To understand this repression, it is necessary to look at the ways in which women's management of household economies impacted the economic and legal sphere.

\footnotetext{
206 Linton, 166.

${ }^{207}$ Abelson, When Ladies Go A-Thieving, 25.
} 


\section{Women's finance}

Despite the fundamentals of money management laid out by Beeton, it appears that not all consuming Victorian women took that advice seriously. Many women of the period who were lured into department stores and gave into sensuous consumption, often did so without their husband's knowledge. The husbands were often made known of the fact only when it was too late and the women racked up a debt. An example of a conversation from a group of married women in The Ladies Paradise can be used to illustrate a case in which a women engages in sensual consumption without the husband's awareness. Madame Marty and a group of friends in conversation:

“'AAnd this?' Madame de Boves asked her, examining a remnant of guipure. "That", she replied, "is for an insertion...There are twenty-six meters. It was on franc a meter, you see!"

"Oh said Madame Bourdelais, surprised, "what are you going to do with it then?"

"I really don’t know...But it had such a pretty pattern!"

At that moment, as she looked up, she caught sight of her terrified husband opposite her. He had become even paler, his whole person expressing the resigned anguish of a poor man witnessing the decimation of his hard-earned salary. Each fresh piece of lace was for him a disaster...Faced with his look of growing alarm, she tried to retrieve the handkerchief, the veil, the scarf, moving her feverish hands about, repeating with little embarrassed laughs: "You'll get me into trouble with my husband...I assure you, my dear, I've been very reasonable...",208

This quote is useful in illustrating a scenario that could have taken place during the late Victorian era. Although the conversation illustrated above takes place in a fictional setting, it is very comparable to the realities of consuming Victorian women. Since consumption and household economy management was the women's role, the husbands all too often were left out in regards to how the household allowance was spent. Zola successfully illustrates the ways in which Madame Marty was overcome with the bargain exchange value of the

${ }^{208}$ Zola, The Ladies' Paradise, 2008, 83. 
commodity and her succumbing to her desires. Despite so accurately depicting this conflict over bargain and desire, Zola does not delve deeper into the thought process behind Madame Marty's consumption. Instead Zola depicts this scene as a problem. A problem of women's lack of control of their inner consumptive desires and lack of rational thought process when coming into contact with sensual consumption. Zola also dramatizes this scene for the purpose of inciting a reaction from the reader rather than engaging in a deeper understanding of the cultural logistics behind Madame Marty's consumptive behavior. This shows that despite Zola in many ways behind ahead of his time in his forward thinking ways, he was at the end of the day, a man of his time. Further, the dramatization of women's consumption and struggle in the public department store shows how readily Zola capitalized on drama and shock for the purposes of inciting public discussions.

Going back to Madame Marty spending her husband's income, women spending their husbands income, was a very common subject and concern in England at the time. Due to the increasing amount of debt's incurred by consuming women during the late nineteenth century, the English Parliament passed a law called the Married Women's Property Act of 1882. This Act, "recognized married women as property owners without making them fully liable for the debts they incurred... putting married women in an unusually strong position to avoid paying for what they purchased." ${ }^{209}$ What was originally intended to be an Act to control women's spending, instead became a safety net for when sensuous consumption got out of hand. The issue of consuming women was a constant problem throughout the late $19^{\text {th }}$ century. Although the 1882 Act recognized women as property owners, it did little to alleviate the financial burden placed on shop owners. This was because husbands could claim that they were "...not legally accountable for their wives debts "unless the wife had the direct

${ }^{209}$ Rappaport, Shopping for Pleasure, 56. 
authority of her husband to pledge his credit" ${ }^{210}$ to which unsurprisingly, very few men agreed to. Considering the cyclical depression and great depression which affected many workers of all establishments throughout the mid-late nineteenth century, the issue of female consumer incurred debt, impacted establishments across England. The monetary impact became so great that many traders advocated for increased women's rights, but not because they cared “for women's emancipation per se, but because they wanted legal recognition for the wife's role as family consumer so that they would not suffer from what had come to be wives' anomalous legal status." ${ }^{211}$ Further, as I have proven throughout my paper thus far, many establishments tailored to the sale of commodities, were very heavily reliant on female consumers. For this reason they couldn't not sell their commodities to women. In order to keep their capitalist businesses going, they had to lure the female shoppers ensure that there was enough demand for the commodities being produced. It was clear that women could not go on consuming and raking up debt the way they did. But it was also impossible to make the husbands liable for the way their wives managed their household economies. As Rappaport explains, it was an ongoing problem:

\begin{abstract}
"While a husband's liability for his wife's consumption steadily decreased after the 1860s, a wife's legal responsibility increased slowly and unevenly...Legal authorities interpreted women's buying as inherently immoral, since it potentially conferred upon wives power over their husband's economic and social position...it becomes quite clear that neither shoppers, shopkeepers, nor judges always understood or acted in accordance with the law. Women often disobeyed husbands, bought what they wanted, and sometimes cheated retailers out of extraordinary sums. When brought to court, they justified these acts by claiming status as the family's consumer and defining consumption as a rational and legitimate economic act." 212
\end{abstract}

The justification of women's consumption as a legitimate act was the very thing that Beeton was stating in her guide. It was expected of a Victorian women to consume on behalf of the

\footnotetext{
${ }^{210}$ Rappaport, 48.

211 Rappaport, 62.

212 Rappaport, 49.
} 
household, it was essentially taught to them. Which is why when it became an issue in the late $19^{\text {th }}$ century, it was so difficult for the English law, politicians and economists alike to define where the boundaries between necessary and overindulgent consumption occurred. A simple answer to this dilemma would be to accept that the consuming middle and lower class women should be liable for the debts they incurred, but this would mean acknowledging women as having rights, ownership and identities, something that the patriarchal Victorian society was not prepared for. This is why, this flawed system remained in place throughout much of the nineteenth century, despite its flaws, and why I argue that the moralist push against sensual consumption was largely an attempt to repress increased women's rights. 


\section{Conclusion}

In this thesis I have presented a variety of arguments, but fundamentally I have shown the ways through which The Ladies Paradise engaged in and compelled a political economic discussion, as well as the reasons why the late Victorians were against unbridled sensual capitalism.

Through The Ladies Paradise, Zola opened up a new realm of political economy, which was accessible to the middle and lower classes, including women. Zola provoked thought and discussion of political economy in ways which were subtle and less likely to be stigmatised. Zola also enabled the consuming classes to engage in political economic discussions without them or their peers being entirely aware that they were doing so. Take for example my point regarding Madame Marty and the bargain she couldn't resist. On the surface it appears that Zola is writing about a woman who was incapable of controlling her consumer desires. But, upon examining further, it is clear that Zola is critiquing the ways in which women consumed, as well as the drivers for them. Linton expands on this discussion by bringing in the discussion of women's rights and the critique on useful versus un-useful labour. In this manner, all readers of Linton and Zola were inevitably being exposed to and were engaging in some form of political discussion. This is significant because, Linton and Zola are example of two people that would otherwise have not had the opportunity to engage in such debates. Particularly so because Zola was French and Linton was a woman. Despite all odds, they became entangled in this political economic debate and managed to do so without sparking mass conservative upheaval. More so, the political economic debate that these two writers engaged in was more representative of the consumer society at the time, than the political economy Marx and Bagehot were writing.

By capitalising on the senses and writing on controversial topics, Linton and Zola both managed to expand their readership and engage more readers of various backgrounds 
and genders in political economic discussions. By discussing sensual capitalism and applying this discussion to Victorian department stores at them time, Zola was able to engage in political economy in a way which was not only socially more acceptable, but also very familiar. In this was Zola demonstrated how important discussions about political economy at the time, were taking place in literary texts rather than Marx's and Bagehot's writings. Granted Linton and Zola both pose their limitations, as I have explained in my paper, but this is not enough to disregard their importance and obvious impact on readers at the time. The understanding of late Victorian political economy that I have presented can potentially aid in shifting our modern day conceptions of nineteenth century political economy and can help us better understand the cultural, historical and social roots of consumption and capitalism going forward. 


\section{Bibliography}

\section{Primary Sources}

\section{Published Primary Sources}

Bagehot, Walter. The Postulates of the English Political Economy. New York, N.Y.: Cosimo Classics, 2006.

Beeton, Isabella. The Book of Household Management ... Ward, Lock, \& Company, 1861. Lynn Linton, Elizabeth. Ourselves, Essays on Women. Chatto and Windus, 1884. http://archive.org/details/ourselvesessays00lintgoog.

- The Girl of the Period: And Other Social Essays. London : Richard Bentley \& Son, 1883. http://archive.org/details/girlofperiodothe01lint

Marx, Karl. Capital: A Critique of Political Economy. V. 1: Penguin Classics. London ; New York, N.Y: Penguin Books in association with New Left Review, 1981.

Vizetelly, Ernest Alfred. Émile Zola, Novelist and Reformer: An Account of His Life \& Work, 2018.

Zola, Émile. The Ladies' Paradise. Oxford World's Classics. Oxford ; New York: Oxford University Press, 2008.

\section{Newspapers}

‘The Evening Express'. Aberdeen Evening Express. 29 July 1884.

https://www.britishnewspaperarchive.co.uk/viewer/bl/0000444/18840729/001/0002.

‘Women On Women’s Movements'. Bicester Herald, 5 November 1886.

https://www.britishnewspaperarchive.co.uk/viewer/BL/0002292/18861105/104/0007? browse $=$ False . 
'Zola’s Works In English'. Birmingham Daily Post, 1 November 1888.

https://www.britishnewspaperarchive.co.uk/viewer/BL/0000033/18881101/012/0005? browse $=$ False .

'Women's Rights'. Buckingham Advertiser and Free Press, March 1882.

https://www.britishnewspaperarchive.co.uk/viewer/bl/0001081/18820318/033/0003.

‘A Ladies’ Paradise'. Bucks Herald, 5 May 1888.

https://www.britishnewspaperarchive.co.uk/viewer/bl/0000270/18880505/003/0002.

'Mrs. Fawcett On Women's Rights'. Bury and Norwich Post, 26 October 1886.

https://www.britishnewspaperarchive.co.uk/viewer/bl/0000156/18861026/021/0003.

‘The Council On Women's Rights'. Chester Courant, 17 March 1886.

https://www.britishnewspaperarchive.co.uk/viewer/bl/0000391/18860317/071/0006.

'New Phase Of The Women's Rights Question'. Dundee Evening Telegraph, 19 May 1884.

https://www.britishnewspaperarchive.co.uk/viewer/b1/0000453/18840519/015/0002.

‘Occasional Notes'. Edinburgh Evening News. 1 December 1884.

https://www.britishnewspaperarchive.co.uk/viewer/bl/0000452/18841201/003/0002.

‘Women’s Rights In France'. Edinburgh Evening News, 14 August 1880.

https://www.britishnewspaperarchive.co.uk/viewer/bl/0000452/18800814/068/0004.

‘Women's Rights Progress'. Essex Herald, 9 October 1882.

https://www.britishnewspaperarchive.co.uk/viewer/bl/0001635/18821009/057/0004 .

‘The Rewards Of Literature'. Exeter and Plymouth Gazetter, 29 December 1887.

https://www.britishnewspaperarchive.co.uk/viewer/BL/0000508/18871229/089/0008? browse $=$ False .

'Zola'. Freedom. 1 November 1902.

https://www.britishnewspaperarchive.co.uk/viewer/BL/0003243/19021101/003/0002? browse $=$ False . 
'Literature'. Freeman's Journal. 7 December 1883.

https://www.britishnewspaperarchive.co.uk/viewer/BL/0000056/18831207/004/0002? browse $=$ False.

‘Advertisement The Ladies' Paradise English Version'. Globe, 11 January 1883. https://www.britishnewspaperarchive.co.uk/viewer/bl/0001652/18830111/083/0008.

'The Ladies' Paradise English Version Of The Great Story By Émile Zola'. Globe, 11 January 1883.

https://www.britishnewspaperarchive.co.uk/viewer/b1/0001652/18830111/083/0008.

‘Popular New Novels At Every Library'. Illustrated London News, 13 October 1883. https://www.britishnewspaperarchive.co.uk/viewer/bl/0001578/18831013/053/0015.

'Is Society Getting Worse ? Another Jeremiad From Mrs. Lynn Lynton'. Manchester Courier and Lancashire General Advertiser. 1 April 1893.

https://www.britishnewspaperarchive.co.uk/viewer/BL/0000206/18930401/197/0016? browse $=$ False.

'Parisine'. Manchester Evening News. 22 August 1887.

https://www.britishnewspaperarchive.co.uk/viewer/bl/0000272/18870822/004/0002.

‘A Woman’s View Of Zola’. Newcastle Daily Chronicle. 4 January 1889.

https://www.britishnewspaperarchive.co.uk/viewer/BL/0001634/18890104/035/0004? browse $=$ False.

'The Shop Girls Of Paris'. Newcastle Daily Chronicle. 9 September 1892.

https://www.britishnewspaperarchive.co.uk/viewer/BL/0001634/18920909/043/0004? browse $=$ False.

‘Mr. Stanley At Melchp'. Newcastle Evening Chronicle. 15 July 1890.

'Reviews'. Norwood News. 17 April 1886.

https://www.britishnewspaperarchive.co.uk/viewer/bl/0002308/18860417/131/0005. 
'Mrs. Beecher's Good-Bye To England'. Pall Mall Gazette. 16 November 1886.

https://www.britishnewspaperarchive.co.uk/viewer/BL/0000098/18861116/014/0014?browse $=$ true.

‘The Gospel According To Robert Browning'. Pall Mall Gazette. 5 June 1888.

https://www.britishnewspaperarchive.co.uk/viewer/BL/0000098/18880605/002/0002? browse $=$ true.

'The War In Zululand'. Reynold's Newspaper. 29 July 1888.

https://www.britishnewspaperarchive.co.uk/viewer/bl/0000101/18880729/041/0005.

‘Summary Of News'. Sheffield Daily Telegraph. 10 January 1890.

https://www.britishnewspaperarchive.co.uk/viewer/bl/0000250/18900110/008/0004 .

'New Volume Zola's Realistic Novels'. Sheffield Daily Telegraph, 28 September 1886.

https://www.britishnewspaperarchive.co.uk/viewer/bl/0000250/18860928/183/0004.

'Women's Rights and The Reform'. Shields Daily News, 24 April 1884.

https://www.britishnewspaperarchive.co.uk/viewer/bl/0001168/18840424/048/0003.

'Women's Rights Meeting at New Swindon'. Swindon Advertiser and North Wilts

Chronicle, 16 December 1882.

https://www.britishnewspaperarchive.co.uk/viewer/b1/0000675/18821216/077/0003.

'M. Zola’s New Book'. The Queen, 5 March 1898.

https://www.britishnewspaperarchive.co.uk/viewer/bl/0002627/18980305/139/0019.

‘Émile Zola’s Novels'. Time Of India, 21 June 1884.

https://www.britishnewspaperarchive.co.uk/viewer/b1/0002850/18840621/012/0001.

'Tins Tovno Pinson \& Gail'. Toronto Daily Mail. 29 March 1890.

https://www.britishnewspaperarchive.co.uk/viewer/bl/0002933/18900329/094/0005.

'Our Literary Letter'. Willesden Chronicle. 7 June 1889.

https://www.britishnewspaperarchive.co.uk/viewer/bl/0001721/18890607/081/0007. 
'Lecture On " Women's Rights'. Windsor and Eton Express, 22 November 1884.

https://www.britishnewspaperarchive.co.uk/viewer/bl/0000413/18841122/060/0002.

\section{$\underline{\text { Secondary Sources }}$}

Abelson, Elaine S. When Ladies Go A-Thieving: Middle-Class Shoplifters in the Victorian Department Store. Oxford University Press, 1992.

Albritton, Robert. A Japanese Approach to Stages of Capitalist Development. Basingstoke, Hampshire: Macmillan, 1991.

Anderson, Nancy F. (Nancy Fix). Woman against Women in Victorian England : A Life of Eliza Lynn Linton. Bloomington : Indiana University Press, 1987. http://archive.org/details/womanagainstwome00ande.

Bloom, Harold, ed. The Victorian Novel. Bloom's Period Studies. Philadelphia: Chelsea House, 2004.

Brewer, John, and Roy Porter. Consumption and the World of Goods. Psychology Press, 1994.

Broomfield, Andrea L. 'Eliza Lynn Linton, Sarah Grand and the Spectacle of the Victorian Woman Question: Catch Phrases, Buzz Words and Sound Bites'. English Literature in Transition 1880-1920 47, no. 3 (22 June 2004): 251-73.

. 'Much More than an Antifeminist: Eliza Lynn Linton's Contribution to the Rise of Victorian Popular Journalism'. Victorian Literature and Culture 29, no. 2 (2001): $267-83$.

Burton, Antoinette M. Burdens of History: British Feminists, Indian Women, and Imperial Culture, 1865-1915. Chapel Hill: University of North Carolina Press, 1994.

Cain, P. J., and A. G. Hopkins. British Imperialism: 1688-2015. Routledge, 2016.

Colley, Linda. Britons: Forging the Nation, 1707-1837. Yale University Press, 2005. 
Crossick, Geoffrey, and Serge Jaumain. Cathedrals of Consumption: European Department Stores, 1850-1939. Routledge, 2019.

Fletcher, T. W. 'The Great Depression of English Agriculture 1873-1896'. The Economic History Review 13, no. 3 (1961): 417-32. https://doi.org/10.1111/j.14680289.1961.tb02128.x.

Gore, Clare Walker. 'The Sensational Eliza Lynn Linton'. Women: A Cultural Review 27, no. 3 (2 July 2016): 329-31. https://doi.org/10.1080/09574042.2016.1256122.

Grant, James. Bagehot: The Life and Times of the Greatest Victorian. Illustrated Edition. New York: W. W. Norton \& Company, 2019.

Gurney, Peter. The Making of Consumer Culture in Modern Britain. Bloomsbury Publishing, 2017.

Howes, David. Sensual Relations Engaging the Senses in Culture and Social Theory. Ann Arbor: University of Michigan Press, 2003.

Jones, Gareth Stedman. Outcast London: A Study in the Relationship Between Classes in Victorian Society. Verso Books, 2014.

Lapp, John C. 'The Critical Reception of Zola's Confession de Claude'. Modern Language Notes 68, no. 7 (1953): 457-62. https://doi.org/10.2307/3043654.

Malheiro, B. 'Victorian Money'. Accessed 16 November 2020. https://logicmgmt.com/1876/living/money.htm.

Mariz, George. 'Gender and the Victorian Periodical'. Victorian Periodicals Review 38, no. 1 (18 May 2005): 112-13. https://doi.org/10.1353/vpr.2005.0008.

McNall, Scott G. 'You Are What You Eat: Some Thoughts on Consumption and Marxist Class Theory'. Mid-American Review of Sociology 14, no. 1/2 (1990): 45-52.

Rappaport, Erika Diane. Shopping for Pleasure: Women in the Making of London's West End. Princeton University Press, 2001. 
Richards, Thomas. The Commodity Culture of Victorian England: Advertising and Spectacle, 1851-1914. Stanford University Press, 1990.

Rosen, Dr Bruce. 'Victorian History: Income vs Expenditure in Working-Class Victorian England'. Victorian History (blog), 19 June 2014. http://vichist.blogspot.com/2014/05/income-vs-expenditure-in-working-class.html.

Sanders, Lise. Consuming Fantasies: Labor, Leisure, and the London Shopgirl, 1880-1920. Ohio State University Press, 2006.

Sylvanus Urban (pseud. ), [from old catalog] ed, Edward Cave, David Henry, John Nichols, J. B. (John Bowyer) Nichols, John Mitford, John Gough Nichols, et al. The Gentleman's Magazine. Vol. 246. London, 1880.

http://archive.org/details/gentlemansmagaz148unkngoog.

Zweiniger-Bargielowska, Ina. Austerity in Britain: Rationing, Controls, and Consumption, 1939-1955. Illustrated edition. Oxford ; New York: OUP Oxford, 2000. 